\title{
Natural and Bioinspired Phenolic Compounds as Tyrosinase Inhibitors for the Treatment of Skin Hyperpigmentation: Recent Advances
}

\author{
Lucia Panzella *(1) and Alessandra Napolitano \\ Department of Chemical Sciences, University of Naples “Federico II”, I-80126 Naples, Italy; alesnapo@unina.it \\ * Correspondence: panzella@unina.it; Tel.: +39-081-674-131
}

Received: 1 August 2019; Accepted: 13 September 2019; Published: 1 October 2019

\begin{abstract}
One of the most common approaches for control of skin pigmentation involves the inhibition of tyrosinase, a copper-containing enzyme which catalyzes the key steps of melanogenesis. This review focuses on the tyrosinase inhibition properties of a series of natural and synthetic, bioinspired phenolic compounds that have appeared in the literature in the last five years. Both mushroom and human tyrosinase inhibitors have been considered. Among the first class, flavonoids, in particular chalcones, occupy a prominent role as natural inhibitors, followed by hydroxystilbenes (mainly resveratrol derivatives). A series of more complex phenolic compounds from a variety of sources, first of all belonging to the Moraceae family, have also been described as potent tyrosinase inhibitors. As to the synthetic compounds, hydroxycinnamic acids and chalcones again appear as the most exploited scaffolds. Several inhibition mechanisms have been reported for the described inhibitors, pointing to copper chelating and/or hydrophobic moieties as key structural requirements to achieve good inhibition properties. Emerging trends in the search for novel skin depigmenting agents, including the development of assays that could distinguish between inhibitors and potentially toxic substrates of the enzyme as well as of formulations aimed at improving the bioavailability and hence the effectiveness of well-known inhibitors, have also been addressed.
\end{abstract}

Keywords: pigmentary disorders; mushroom tyrosinase; human tyrosinase; melanin; depigmenting agent; inhibition mechanism; phenolic compounds; resorcinol; hydroxycinammic acids; chalcones

\section{Introduction}

The quest for skin lighteners and agents capable of controlling hyperpigmentation disorders is growing at a sustained pace particularly in Asian countries. Most of the strategies explored so far focus on the control of the activity of tyrosinase, which is the main, rate-limiting enzyme involved in the biosynthesis of melanins, the pigments responsible for skin pigmentation in mammals [1-5].

This work will provide an overview of the tyrosinase inhibition properties of natural phenolic compounds, phenols inspired by active compounds of natural origin, or synthetic phenols as appeared in the literature (data source: SciFinder ${ }^{\circledR}$, search terms: tyrosinase inhibition) in the last five years. Patents were excluded since the main aim of this review is an update of those compounds that have a potential for further development, though possibly not yet ready for a straightforward use in cosmetics.

Beside product efficacy, cytotoxicity, solubility, cutaneous absorption, and stability, other critical issues that should be carefully considered when developing a new tyrosinase inhibitor include adverse effects derived from action of the enzyme itself on the product as largely documented in the recent case of rhododendrol, a depigmenting agent on the market capable of inducing leukoderma [6-8]. In this perspective the different mechanisms by which tyrosinase inhibition occurs will be presented in the following paragraphs. 
Given the difficulties of obtaining mammalian tyrosinase, most of the studies have been carried out on fungal (mushroom) tyrosinase, which however exhibits somewhat different substrate specificity [9]. Starting from consideration of the structural features of the most widely investigated classes of tyrosinase inhibitors, a rationalization of the structural requirements to get the inhibitory activity, stemming also from model or docking studies, will be offered. Finally, issues of toxicity of potential tyrosinase inhibitors and the limitations of the in vitro studies using mushroom tyrosinase will be discussed in the perspective of developing effective and safe tyrosinase inhibitors. Data on recent trends in cosmetic formulations to improve bioavailability and efficiency of well-known tyrosinase inhibitors will be also presented.

\section{Skin Pigmentation and Hyperpigmentary Disorders}

Skin pigmentation in humans is dependent mainly on the quantity, type, and distribution of melanins in the epidermis. The resulting pigmentation can be changed by phenomena of light reflection and diffusion, or by the presence of pigments of a different kind, occasionally present in the skin $[10,11]$.

Apart from the hemoglobin and the biliary pigments, melanins are the only pigments to be biosynthesized in humans. They are produced in melanocytes lying in the epidermis at the dermal-epidermal junction and then transferred in the form of organelles termed melanosomes to neighboring keratinocytes in the skin (Figure 1) [12-15].
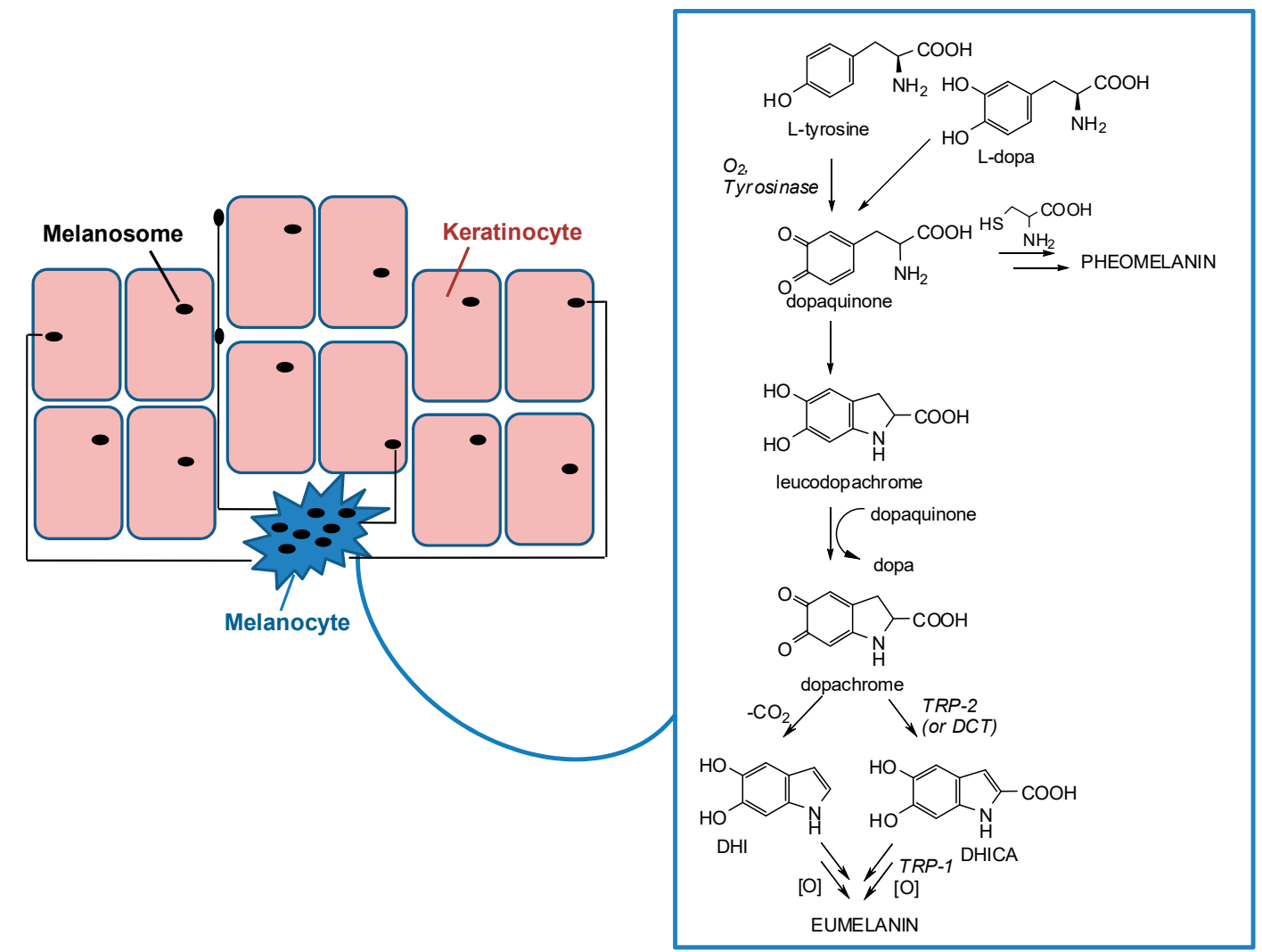

Figure 1. Schematic representation of melanosome transfers from melanocytes to keratinocytes and melanogenesis pathway inside melanocytes.

Under normal physiological conditions, pigmentation has a beneficial effect on the photoprotection of human skin against harmful UV injury [16]. However increased pigmentation, especially on the face, such as in the case of melasma, solar lentigo (age spots), and lentigo simplex (freckles), presents a significant cosmetic bother and can cause distress to the affected individual. Increased melanin synthesis and accumulation occurs also in other skin problems and systemic or idiopatic diseases [17-22]. 
Hyperpigmentation can also occur through inflammation of the skin, chronic heat exposure, hormonal imbalance, mechanical stimulation, and medication applications.

\section{Tyrosinase and its Key Role in Melanin Synthesis}

Melanogenesis is a complex pathway involving a combination of enzymatic and chemical catalyzed reactions. Melanosomes produce two types of melanin: eumelanin, a brown-black or dark polymer, and pheomelanin, a red-yellow polymer, formed by intervention of cysteine (Figure 1). The melanogenesis process is initiated with the oxidation of L-tyrosine to dopaquinone by tyrosinase. The formation of dopaquinone is a rate-limiting step in melanin synthesis because the remainder of the reaction sequence can proceed spontaneously at a physiological $\mathrm{pH}$ value. Following its formation, dopaquinone undergoes intramolecular cyclization to produce leucodopachrome. The redox exchange between leucodopachrome and dopaquinone then gives rise to dopachrome and L-3,4-dihydroxyphenylalanine (L-dopa), which is also a substrate for tyrosinase and is oxidized to dopaquinone again by the enzyme. Finally, dopachrome undergoes a rearrangement to give 5,6-dihydroxyindole (DHI) and 5,6-dihydroxyindole-2-carboxylic acid (DHICA) (Figure 1). This latter process is catalyzed by tyrosinase related protein-2 (TRP-2), known also as dopachrome tautomerase (DCT). Ultimately, DHI and DHICA are oxidized to melanin pigments. Tyrosinase related protein 1 (TRP-1) is believed to catalyze the oxidation of DHICA to melanin. Although all the three enzymes, tyrosinase, TRP-1, and TRP-2 are involved in the melanogenesis pathway, tyrosinase is exclusively necessary for melanogenesis [11,23-30].

Tyrosinase (EC 1.14.18.1, monophenol, ortho-diphenol: oxygen oxidoreductase) is a multifunctional membrane bound type-3 copper-containing glycoprotein located in the membrane of the melanosome. From the structural point of view, two copper ions are surrounded by three histidine residues that are responsible for the catalytic activity of tyrosinase. Substrates for tyrosinase are generally either phenols, which undergo monooxygenation (monophenolase or cresolase activity), or catechols, which undergo oxidation (diphenolase or catecholase activity), leading in both cases to ortho-quinones (Figure 2a) [31,32]. Although the view that phenol oxidation involves a hydroxylation step followed by catechol oxidation is still commonly claimed in the literature $[33,34]$, in the monophenolase mechanism the ortho-quinone is formed directly from the phenol, and catechol formation is not an intermediate step [35]. During the catalytic cycle the oxidation states of the copper atoms change to give different forms of the enzyme (Figure $2 b-d$ ).

The active site of the enzyme has three states: oxy, met, and deoxy forms. The oxidation of phenols to ortho-quinones by oxy-tyrosinase is the most important function of the enzyme and it is by this process that L-tyrosine is converted to dopaquinone in the biosynthesis of melanins (Figure 2b). Mechanistically, the oxygen of the phenol is believed to bind to $\mathrm{CuA}$ followed by electrophilic monooxygenation of the ring leading to a complex in which the substrate is bound to both copper ions. In a further step such complex undergoes homolytic dissociation to give the ortho-quinone and deoxy-tyrosinase. The deoxy-tyrosinase then binds oxygen to regenerate $o x y$-tyrosinase and the phenol-oxidation cycle continues until the phenol and/or oxygen are depleted [35]. 


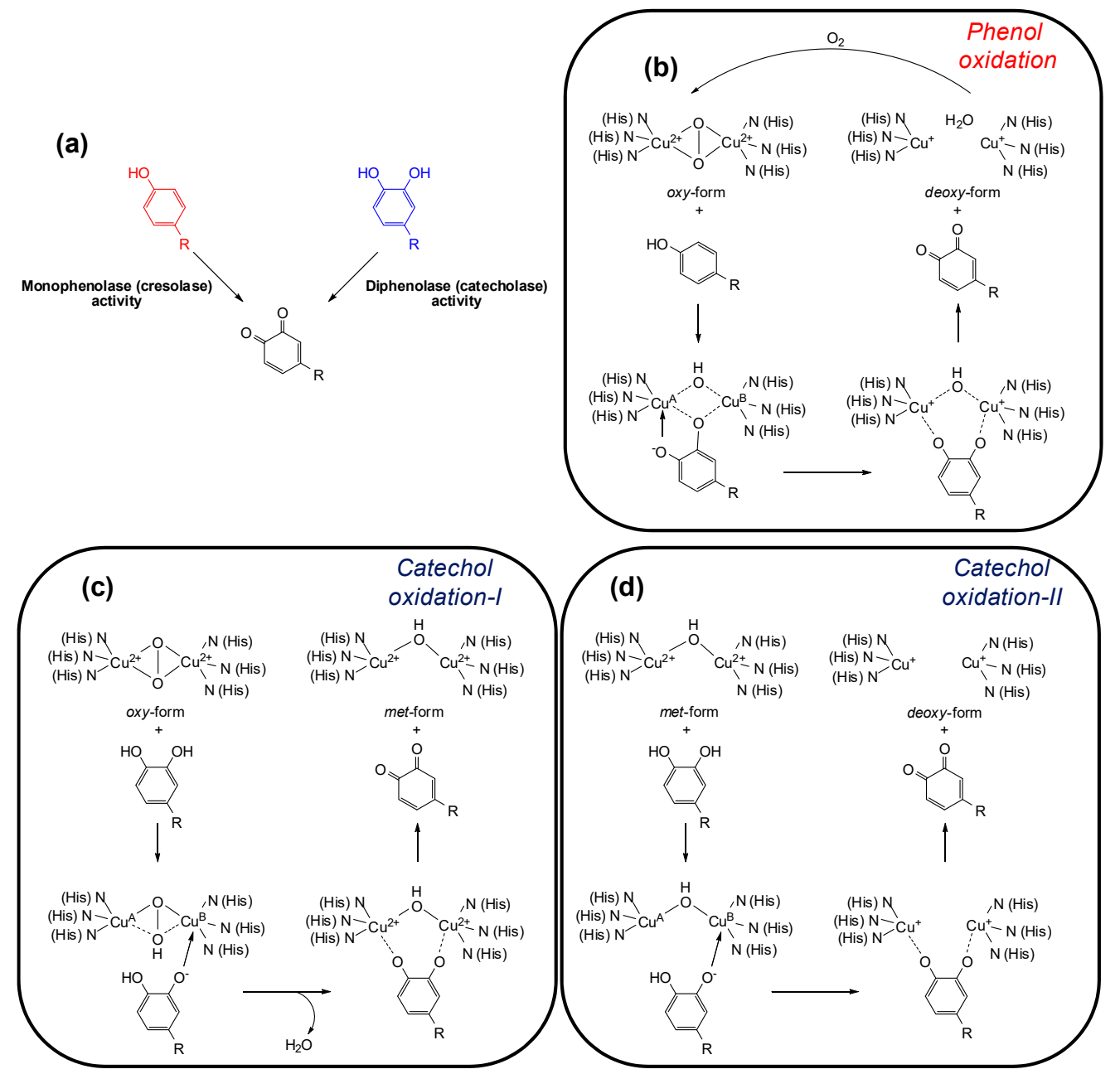

Figure 2. (a) Tyrosinase-catalyzed reactions; (b-d) oxidation states of tyrosinase and their conversions by phenols/catechols [35].

Oxy-tyrosinase is able to oxidize catechols in addition to phenols. In many cases, a higher specific activity for catechol oxidation than for the corresponding phenol oxygenation has been observed [36]. This is possibly a consequence of the ease of substrate orientation on binding to the active site: whereas monohydric phenols bind to $\mathrm{CuA}$, catechols initially bind to the active site through the $\mathrm{CuB}$. The oxidation cycle of catechols involves two steps (Figure 2c,d) and in both the binding of the catecholic substrate occurs by deprotonation of the adjacent hydroxyl groups such that the oxygens are coordinated with the two active site copper atoms. In the first step, in which oxy-tyrosinase is converted to met-tyrosinase (Figure 2c), the catechol/enzyme complex dissociates with the release of one of the oxygen atoms from the peroxy conformation of the bound dioxygen yielding the corresponding ortho-quinone and water. The resultant met form of the enzyme retains the oxidation state of the active site copper ions [Cu(II)] to which the remaining oxygen atom is coordinated, probably in a protonated form. Overall, the catechol has reduced the peroxy bridge with formation of water and has been oxidized to an ortho-quinone. In the second stage of the catechol cycle, a second molecule of catechol reduces the active site $\mathrm{Cu}(\mathrm{II})$ ions to $\mathrm{Cu}(\mathrm{I})$ giving deoxy-tyrosinase and a second molecule of orhto-quinone (Figure $2 \mathrm{~d}$ ). The oxidation states of the active site copper ions $[\mathrm{Cu}(\mathrm{II})]$ are then restored by binding dioxygen (Figure 2b) [35].

Tyrosinases have been isolated and purified from different sources such as plants, animals, and microorganisms. Although many of them (such as human) have been sequenced, only few have been characterized. Mushroom tyrosinase from Agaricus bisporus is a major and cheap enzyme, with high 
similarity and homology compared to human tyrosinase $[1,37,38]$. Due to the above-mentioned good properties, the structural, functional, and biochemical characteristics of mushroom tyrosinase have been studied extensively as a model system for screening of tyrosinase inhibitors and melanogenic studies, enzyme-catalyzed reactions, and enzyme-inhibitor structural studies so far [1,39-41]. Tyrosinase from A. bisporus is a $120 \mathrm{kDa}$ tetramer, which was first isolated by Bourquelot and Bertrand in 1895 [42]. It has three domains and two copper binding sites composed of six histidine residues able to interact with molecular oxygen in the active site. It should be cautioned that tyrosinase from mushroom is very different from human tyrosinase. Mushroom tyrosinase is a tetramer enzyme present in the cytosol of the cells, while human tyrosinase is a monomeric and inactive glycosylated membrane bound form. Furthermore, tyrosinases from different sources exhibit quite different substrate specificity, e.g., human tyrosinase shows higher (up to 6-fold) affinity for L-DOPA oxidation activity than the mushroom tyrosinase [31]. In addition, the amino acid sequence identity between human and mushroom tyrosinase is only very limited (23\%) [41].

\section{Tyrosinase Inhibition Mechanisms}

Among different types of compounds able to inhibit melanogenesis, such as specific tyrosinase inactivators and inhibitors, dopaquinone scavengers, alternative enzyme substrates, nonspecific enzyme inactivators and denaturants, only specific tyrosinase inactivators and reversible inhibitors actually bind to the enzyme and really inhibit its activity [1].

Suicide inactivators have been widely reported for the control of hyperpigmentation processes. To explain the suicide inactivation of tyrosinase, mainly two mechanisms have been proposed. It has been suggested that the conformational changes triggered by the inhibitor compound in the tertiary and quaternary structures of tyrosinase might be the real reason for the suicide inactivation. On the other hand, it has also been proposed that suicide inactivation could occur after the transfer of a proton to the peroxy bridge on the active site of $o x y$-tyrosinase [1,43-45].

As far as the true inhibitors are concerned, four types of mechanism have been described: competitive, uncompetitive, mixed type (competitive/uncompetitive), and noncompetitive. A competitive inhibitor can bind to a free enzyme and prevents substrate binding to the enzyme active site. This is the case of phenolic compounds able to act as copper chelators or compounds structurally mimicking the substrate of tyrosinase. In contrast, an uncompetitive inhibitor can bind only to the enzyme-substrate complex, whereas a mixed inhibitor can bind to both free enzyme and enzyme-substrate complex. Finally, noncompetitive inhibitors bind to the free enzyme and the enzyme-substrate complex with the same equilibrium constant $[1,46]$.

The inhibitory strength is generally expressed as the $\mathrm{IC}_{50}$ value, that is the concentration of inhibitor at which $50 \%$ of the enzyme activity is inhibited. Of course, it must be considered that $\mathrm{IC}_{50}$ values may be incomparable due to the different assay conditions (e.g., substrate and enzyme concentrations, incubation time, source of tyrosinase). Reference compounds commonly used as positive controls in the mushroom tyrosinase inhibition assay are kojic acid and $\beta$-arbutin (Figure 3), which however are very poor inhibitors $\left(\mathrm{IC}_{50}>500 \mu \mathrm{M}\right)$ of human tyrosinase [9,47]. Deoxyarbutin has been recently described as a novel tyrosinase inhibitor, with increased skin penetration and binding affinity to human tyrosinase [48-50].

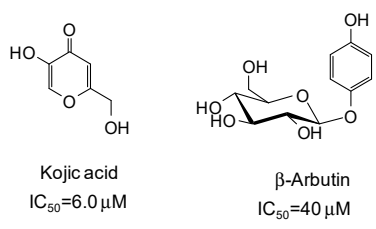

Figure 3. Chemical structures and $\mathrm{IC}_{50}$ values [9] against mushroom tyrosinase of the commonly used reference compounds kojic acid and $\beta$-arbutin. 


\section{Natural Phenolic Inhibitors of Mushroom Tyrosinase}

Among natural phenolic compounds acting as tyrosinase inhibitors (Supplementary Materials, Table S1), flavonoids are the most representative class. Figure 4 shows the structures of the most potent inhibitors with the corresponding $\mathrm{IC}_{50}$ values against mushroom tyrosinase. Among the different subclasses, the highest activity has been determined for chalcones, with 2,2',4,4'-tetrahydroxychalcone exhibiting a very low IC50 value $(0.07 \mu \mathrm{M})$ [51]. A significant melanogenesis inhibition potential has been reported also for galangin $\left(\mathrm{IC}_{50}=3.55 \mu \mathrm{M}\right)$ [52], isoliquiritigenin $\left(\mathrm{IC}_{50}=4.85 \mu \mathrm{M}\right)$ [53], kaempferol $\left(\mathrm{IC}_{50}=5.5 \mu \mathrm{M}\right)$ [54], and dihydromorin $\left(\mathrm{IC}_{50}=9.4 \mu \mathrm{M}\right)$ [55], belonging to different flavonoid subfamilies, but all characterized by at least one resorcinol moiety. IC50 values in the range 20-150 $\mu \mathrm{M}$ have instead been reported for catechins [56-59].

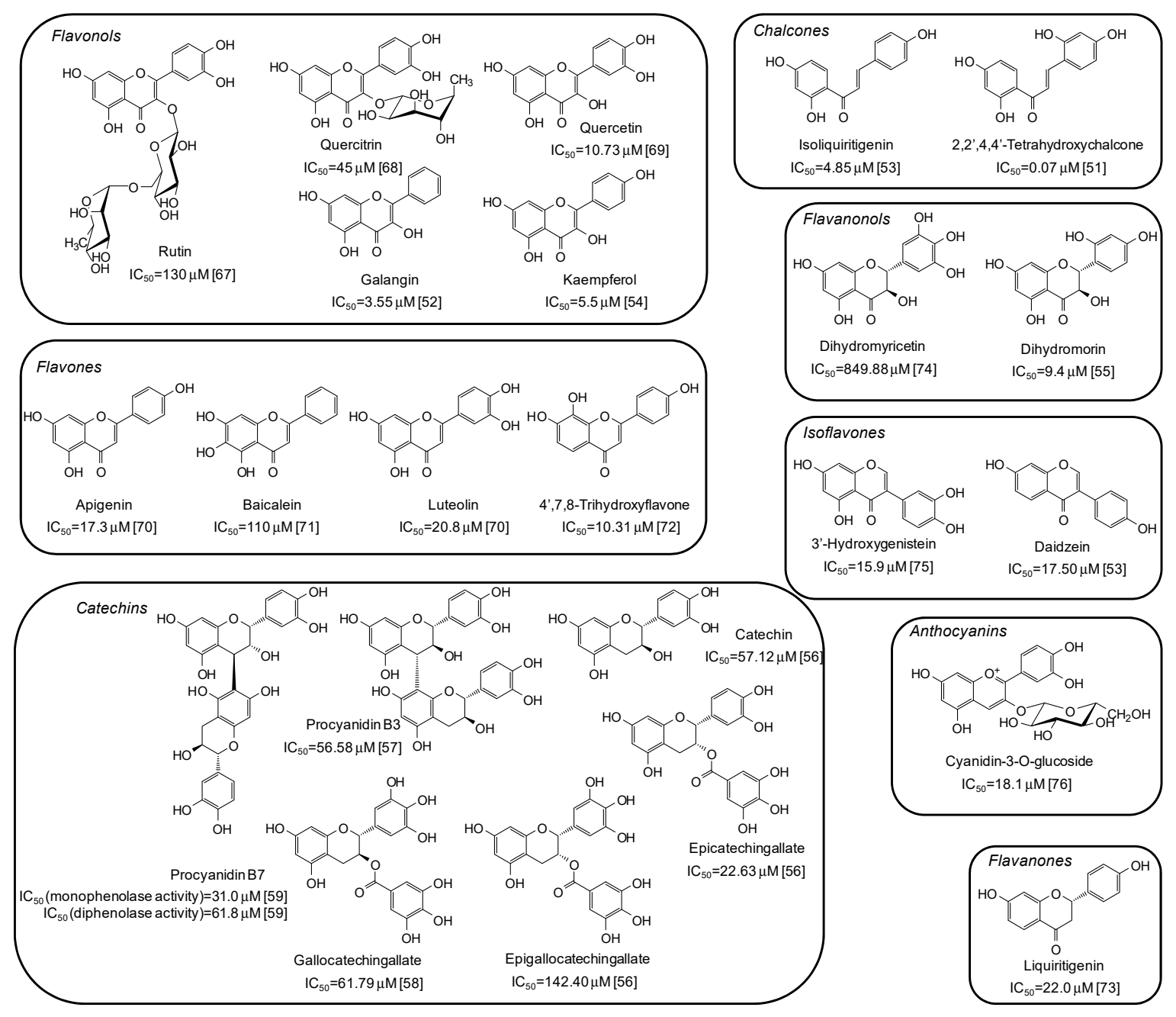

Figure 4. Chemical structures and $\mathrm{IC}_{50}$ values against mushroom tyrosinase of phenolic compounds belonging to the flavonoid class. Unless otherwise specified, $\mathrm{IC}_{50}$ values refer to the diphenolase activity of the enzyme.

Another major class of mushroom tyrosinase inhibitors is represented by hydroxystilbenes (Figure 5). Several derivatives of the parent resveratrol have been described as potential depigmenting agents, with oxyresveratrol $\left(\mathrm{IC}_{50}=1.7 \mu \mathrm{M}\right)[55]$ and particularly dihydrooxyresveratrol $\left(\mathrm{IC}_{50}=0.3 \mu \mathrm{M}\right)[55]$ among the most active compounds. Recently, glycosylation has been reported to improve the tyrosinase inhibitory activities of both resveratrol and its methylated analogues pterostilbene and pinostilbene [60]. 


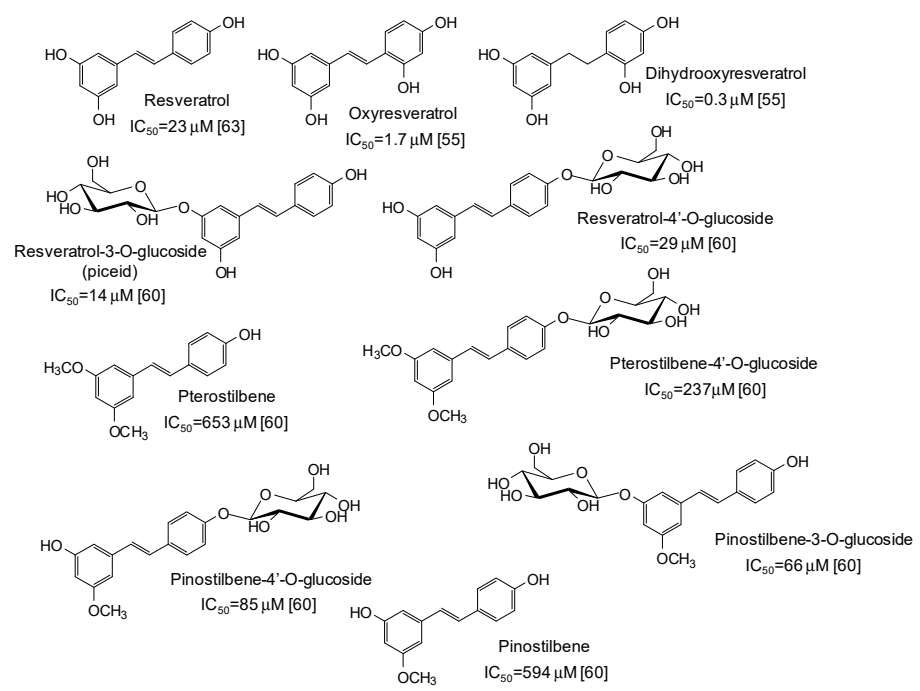

Figure 5. Chemical structures and $\mathrm{IC}_{50}$ values (referring to to the diphenolase activity of the enzyme) against mushroom tyrosinase of hydroxystilbenes.

Moving to simple phenols, significant inhibition activity has been described for 4-hydroxybenzyl alcohol $\left(\mathrm{IC}_{50}=6 \mu \mathrm{M}\right)$ [61] and isoeugenol $\left(\mathrm{IC}_{50}=33.3 \mu \mathrm{M}\right)$ [62], which would appear more efficient than resorcinol [55] or rhododendrol [63] themselves. Other inhibitors have been recently isolated from the roots of Dryopteris crassirhizoma [64] and leaves of Piper aduncum [65] (Figure 6).

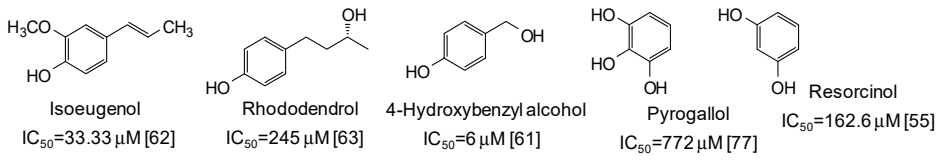

Figure 6. Chemical structures and $\mathrm{IC}_{50}$ values (referring to to the diphenolase activity of the enzyme) against mushroom tyrosinase of simple phenols.

Low $\mathrm{IC}_{50}$ values against both monophenolase and diphenolase activty of mushroom tyrosinase have been very recently reported for $p$-coumaric and caffeic acid [66], belonging to the cinammic acid family (Figure 7).

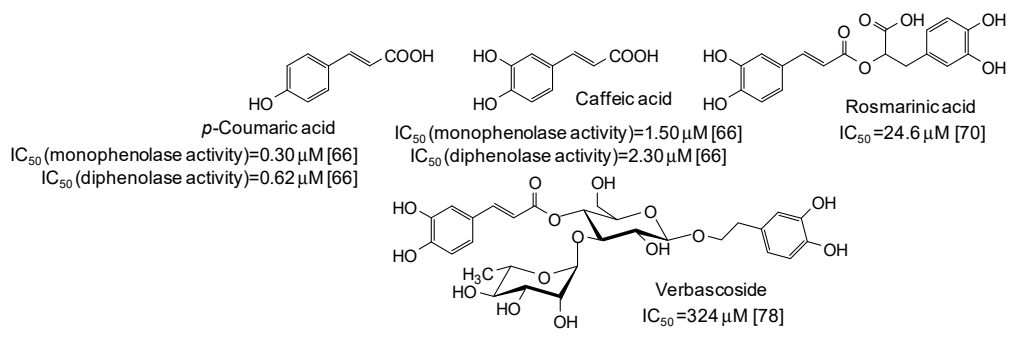

Figure 7. Chemical structures and $\mathrm{IC}_{50}$ values against mushroom tyrosinase of cinnamic acid derivatives. Unless otherwise specified, $\mathrm{IC}_{50}$ values refer to the diphenolase activity of the enzyme.

The $\mathrm{IC}_{50}$ values together with structural formulas for other phenolic compounds widely distributed in nature that have been the subject of studies that appeared in the last five years $[53,62,63,67-82]$ are also reported in Figures 4-8.

A series of more complex phenolic compounds have been isolated from several plants and evaluated as inhibitors against mushroom tyrosinase. The Moraceae family, in particular, has proven to be an important source of potential skin whitening agents [73,83-87] (Figure 9), leading to compounds with in some cases very low $\mathrm{IC}_{50}$ values, such as norartocarpetin (from the stems of Artocarpus rigida, 
$\mathrm{IC}_{50}=0.023 \mu \mathrm{M}$ ) [87], morachalcone A (from the twigs of Artocarpus pithecogallus, $\mathrm{IC}_{50}=0.77 \mu \mathrm{M}$ ) [83], and artocarpanone (from the wood of Artocarpus heterophyllous, $\mathrm{IC}_{50}=2.0 \mu \mathrm{M}$ ) [73], all belonging to the flavonoid family and characterized by the presence of resorcinol ring(s).

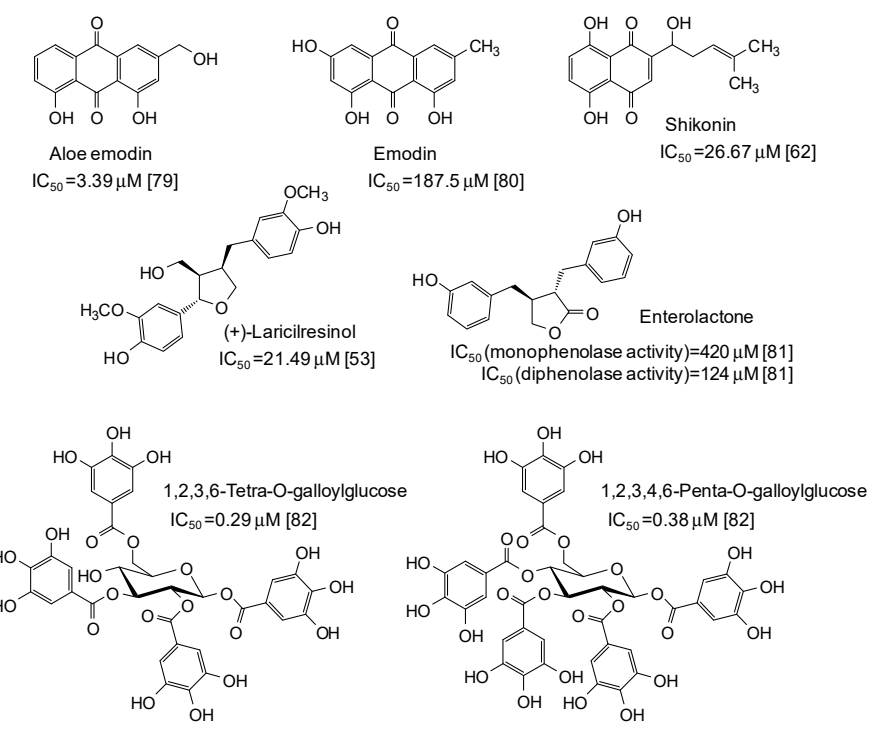

Figure 8. Chemical structures and $\mathrm{IC}_{50}$ values against mushroom tyrosinase of natural phenolic compounds. Unless otherwise specified, $\mathrm{IC}_{50}$ values refer to the diphenolase activity of the enzyme.

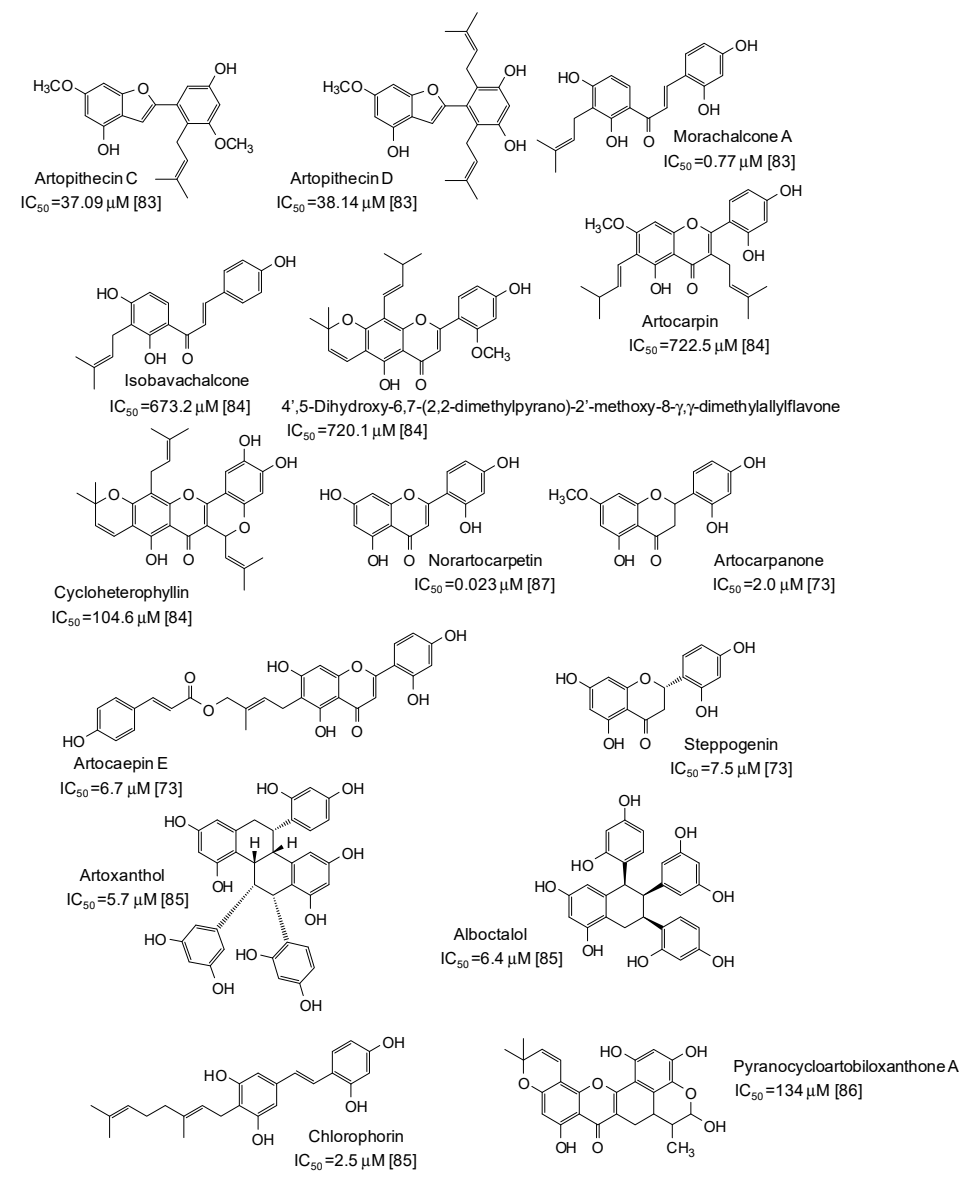

Figure 9. Chemical structures and $\mathrm{IC}_{50}$ values (referring to to the diphenolase activity of the enzyme) against mushroom tyrosinase of phenolic compounds isolated from Artocarpus species (Moraceae family). 
Potent mushroom tyrosinase inhibitors have been isolated also from plants of the genus Morus [55,88-91] (Figure 10): noticeable examples are 2,3',4-trihydroxydihydrostilbene $\left(\mathrm{IC}_{50}=0.8 \mu \mathrm{M}\right)$ [55], the benzofuran moracin $\mathrm{M}\left(\mathrm{IC}_{50}=8.0 \mu \mathrm{M}\right)$ from mulberry (Morus alba) wood [55], and isoprenylated flavanons from Morus nigra, such as kuwanon $\mathrm{J}\left(\mathrm{IC}_{50}=0.17 \mu \mathrm{M}\right)$ and sanggenon $\mathrm{O}$ $\left(\mathrm{IC}_{50}=1.15 \mu \mathrm{M}\right)$ [91] (Figure 10).
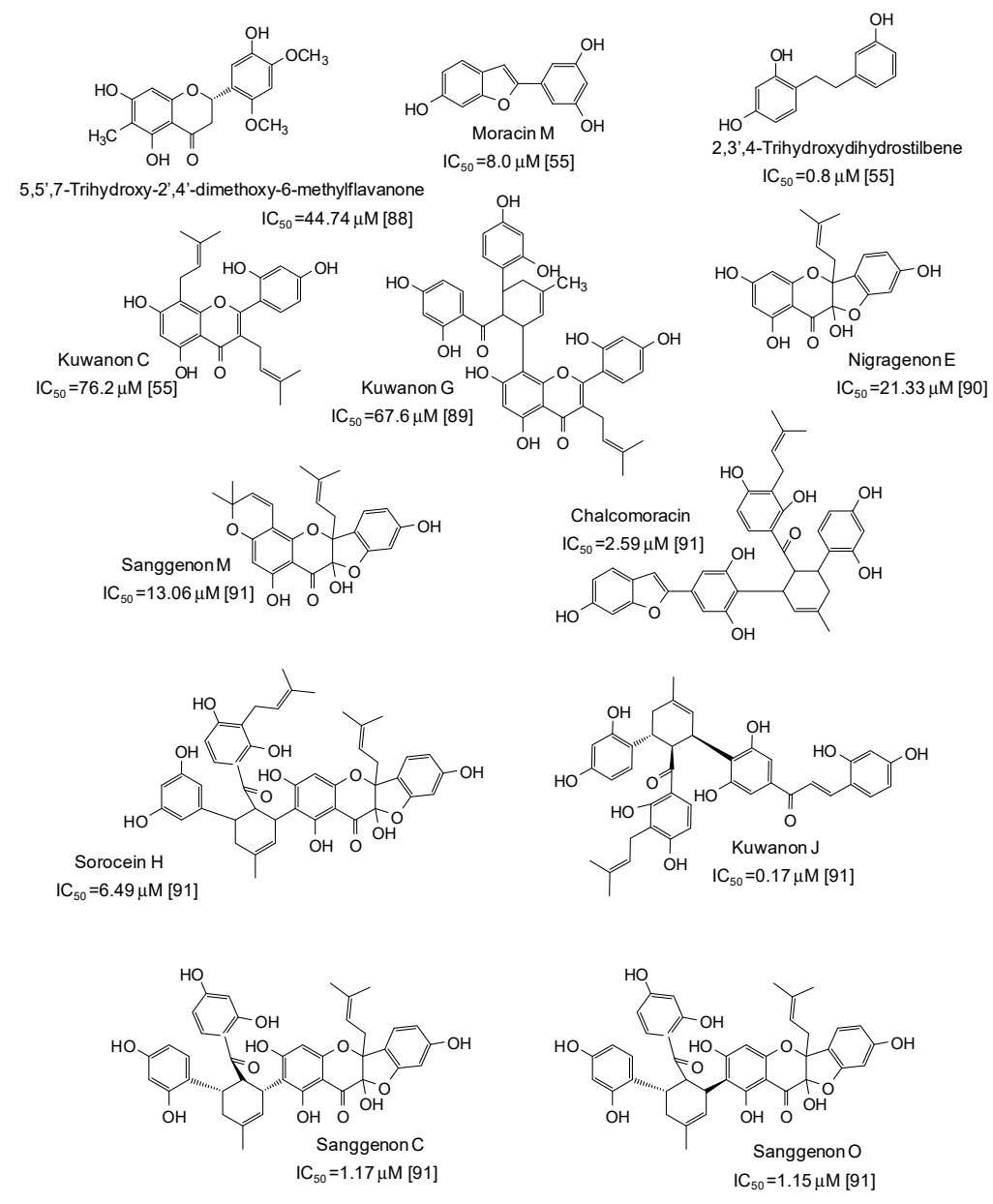

Figure 10. Chemical structures and $\mathrm{IC}_{50}$ values (referring to to the diphenolase activity of the enzyme) against mushroom tyrosinase of phenolic compounds isolated from Morus species (Moraceae family).

A series of flavonoids derivatives from the root bark of Broussonetia papyrifera, first of all broussoflavonol $\mathrm{J}\left(\mathrm{IC}_{50}=9.29 \mu \mathrm{M}\right)$, have been found to be more active than kojic acid as inhibitors of the monophenolase acitivty of the enzyme [92] (Figure 11). Prenylated flavanones from the roots of Dalea pazensis Rusby also proved to be quite effective as mushroom tyrosinase inhibitors [93]. On the contrary, biflavonoids not containing a 1,3-benzenediol from Solanum nigrum (Figure 11) were only poor tyrosinase inhibitos, with $\mathrm{IC}_{50}$ values $>190 \mu \mathrm{M}$ [94]. 


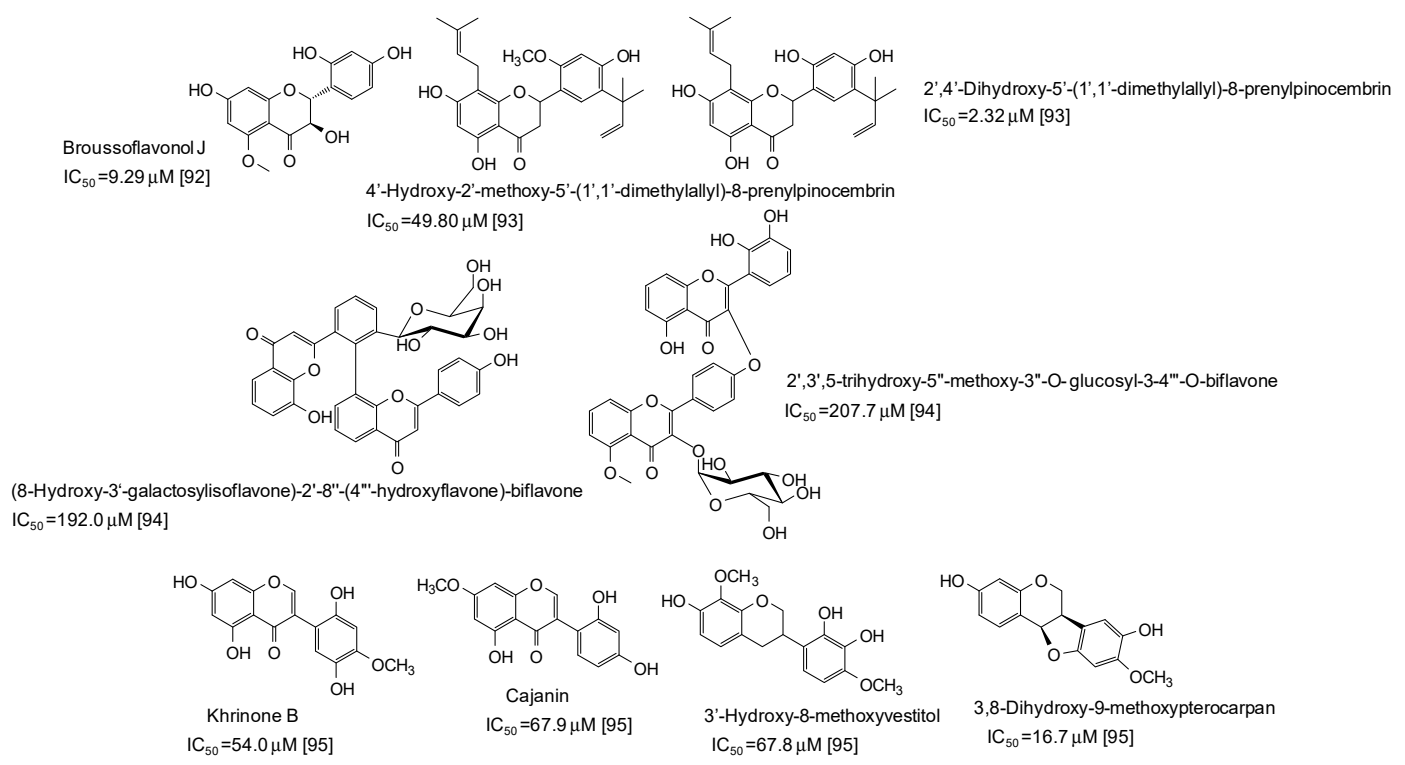

Figure 11. Chemical structures and $\mathrm{IC}_{50}$ values (referring to to the diphenolase activity of the enzyme) against mushroom tyrosinase of flavonoids isolated from different plants.

A pterocarpan $\left(\mathrm{IC}_{50}=16.7 \mu \mathrm{M}\right)$ and some isoflavones and isoflavans isolated from Dalbergia parviflora (Figure 11) have been also recently reported as inhibitors of the diphenolase activity of mushroom tyrosinase [95].

Increasing attention has been devoted to condensed tannins, which have shown promising activities as inhibitors of both monophenolase and diphenolase activity of mushroom tyrosinase (Table 1) [96-107]. Particularly active were prodelphinidins and procyanidins from the fruit pericarp of Clausena lansium Skeels [102], as well as the complex mixtures isolated from Persea Americana [106], Longan bark [99], and from leaves and fruit of Leucaena leucocephala [97].

Table 1. IC $\mathrm{C}_{50}$ values against mushroom tyrosinase reported for condensed tannins isolated from different plants.

\begin{tabular}{ccc}
\hline Source & $\begin{array}{c}\mathbf{I C}_{\mathbf{5 0}}(\boldsymbol{\mu g} / \mathbf{m L}) \\
\text { (Monophenolase Activity) }\end{array}$ & $\begin{array}{c}\text { IC }_{\mathbf{5 0}}(\boldsymbol{\mu g} / \mathbf{m L}) \\
\text { (Diphenolase Activity) }\end{array}$ \\
\hline Vigna angularis [96] & 130.0 & 35.1 \\
Leucaena leucocephala [97] & 52.3 & 16.1 \\
Vigna radiata [98] & 80 & 20 \\
Longan [99] & 43.7 & 11.5 \\
Prunus cerasifera [100] & 738.37 & 137.69 \\
Annona squamosa [101] & 46.5 & 37.3 \\
Clausena lansium [102] & 23.6 & 7.0 \\
Ficus altissima [104] & 256.7 & 41.3 \\
Rhododendron pulchrum [105] & 200 & 200 \\
Persea americana [106] & 40 & 19.5 \\
\hline
\end{tabular}

Very potent $\left(\mathrm{IC}_{50}\right.$ values in the range $\left.0.10-7.5 \mu \mathrm{M}\right)$ mushroom tyrosinase inhibitors have been isolated from licorice (Figure 12), the most active belonging to the isoflavan class [108-110]. Structurally related compounds and paeoniflorin derivatives isolated from San-Bai decoction proved less active ( $\mathrm{IC}_{50}$ in the range 35.54-171.13 $\mu \mathrm{M}$ ) [111] (Figure 12). 


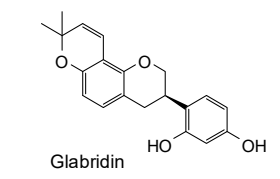

$\mathrm{IC}_{50}=0.10 \mu \mathrm{M}[108]$

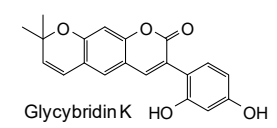

$\mathrm{IC}_{50}=2.8 \mu \mathrm{M}[109]$
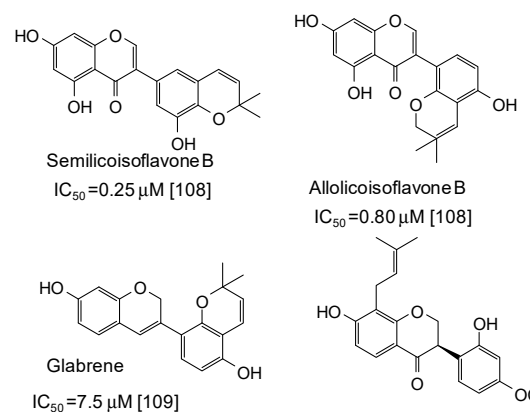

2,7-dihydroxy-4'-methoxy-8-(3-methyl-2-butenyl)isoflavanone $I_{50}=5.1 \mu \mathrm{M}[109]$

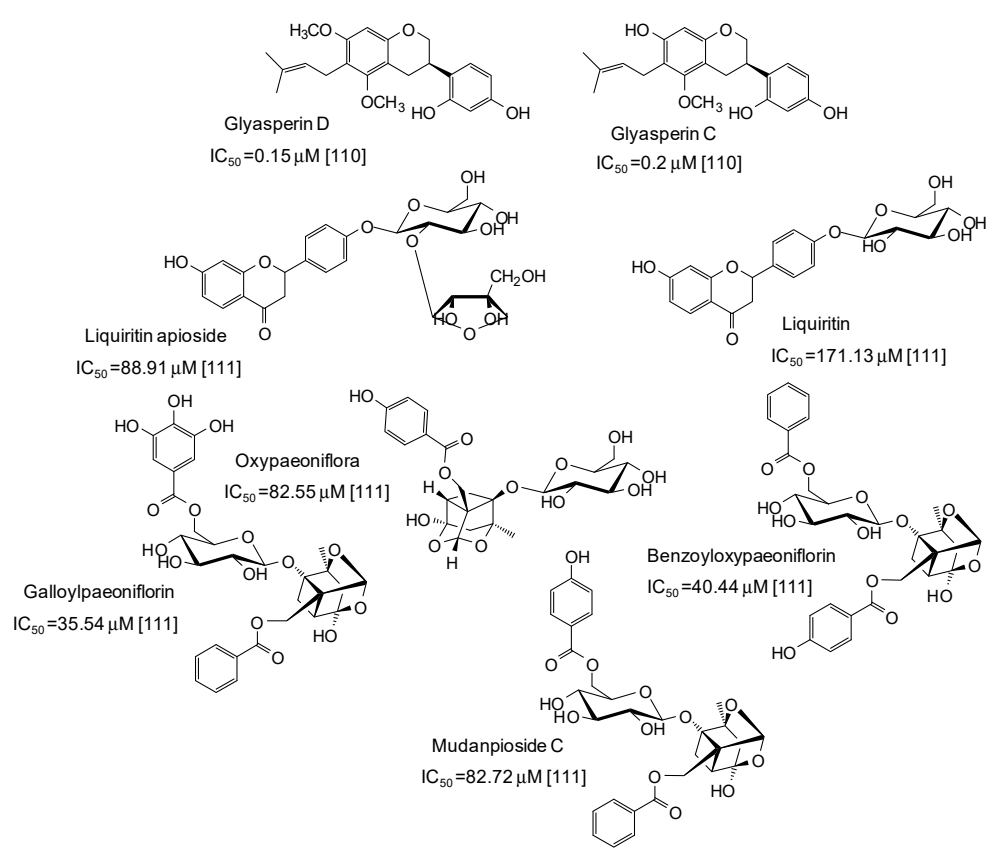

Figure 12. Chemical structures and IC50 values (referring to the diphenolase activity of the enzyme) against mushroom tyrosinase of phenolic compounds isolated from Glycyrrhiza species and San-Bai decoction.

$\mathrm{IC}_{50}$ values in the range $28-42 \mu \mathrm{M}$ have been reported for two lignans isolated from Opilia amentacea leaves [112] (Figure 13), whereas particularly effective against the monophenolase activity of the enzyme were flavonolignans from the seeds of Silybum marianum $\left(\mathrm{IC}_{50}\right.$ in the range $\left.1.7-4.9 \mu \mathrm{M}\right)$ (Figure 13) [113] as well as, although with a lower strength, hydroxylated phenones from Syzygium polyanthum leaves [114] (Figure 14). 


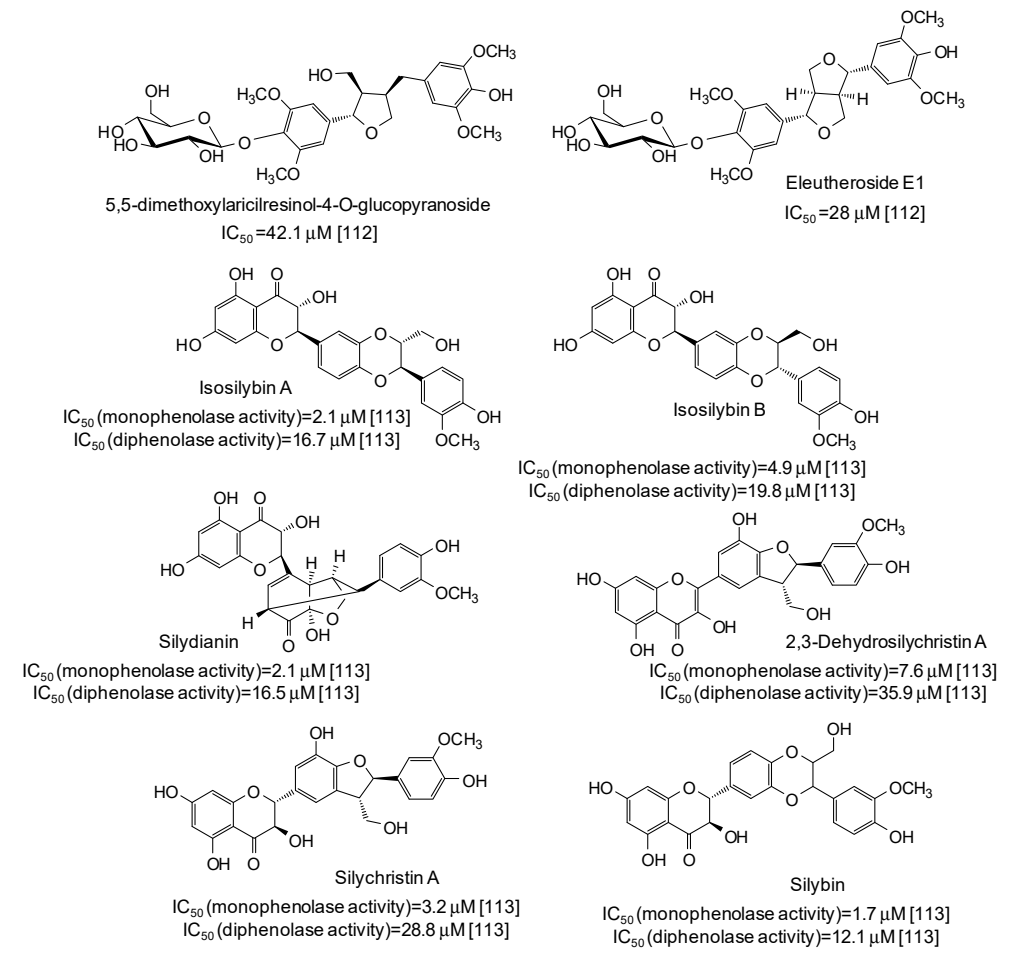

Figure 13. Chemical structures and $\mathrm{IC}_{50}$ values against mushroom tyrosinase of lignans isolated from Opilia amentacea and Silybum marianum. Unless otherwise specified, $\mathrm{IC}_{50}$ values refer to the diphenolase activity of the enzyme.
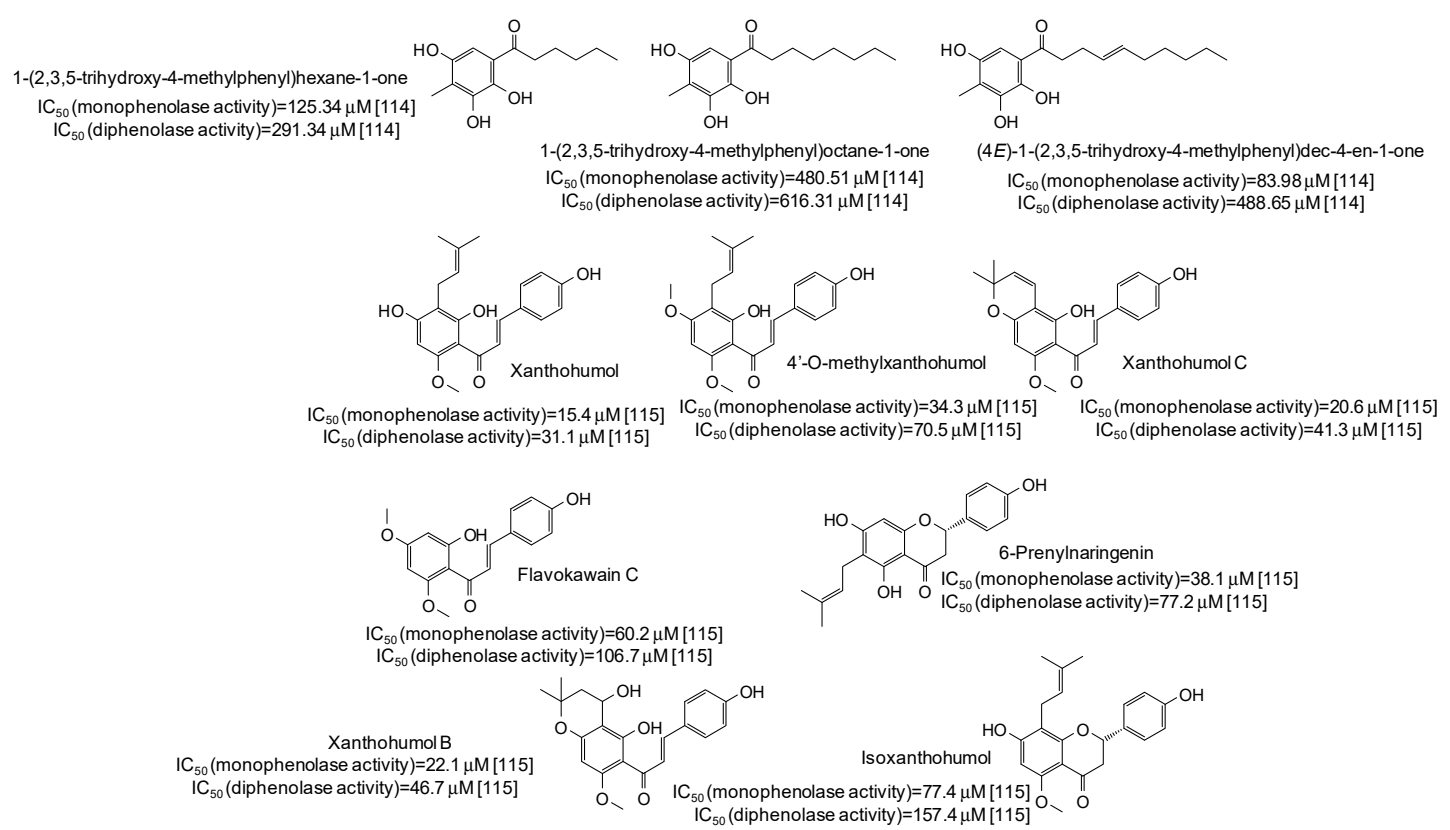

Figure 14. Chemical structures and $\mathrm{IC}_{50}$ values against mushroom tyrosinase of phenolic compounds isolated from Syzygium polyanthum and Humulus lupulus.

Higher inhibition against monophenolase than diphenolase activity of mushroom tyrosinase were reported also for xanthohumol and other chalcones isolated from Humulus lupulus [115] (Figure 14).

Several $p$-coumarate esters from Breynia officinalis leaves have been described as mushroom tyrosinase inhibitors, the most active of which being seguinoside $\mathrm{A} p$-coumarate $\left(\mathrm{IC}_{50}=16.9 \mu \mathrm{M}\right)[116]$ 
(Figure 15), whereas less effective were feruloyl sucrose esters from Oryza sativa roots [117] and epicatechin glucosydes isolated from Breynia fruticosa [118] (Figure 15).
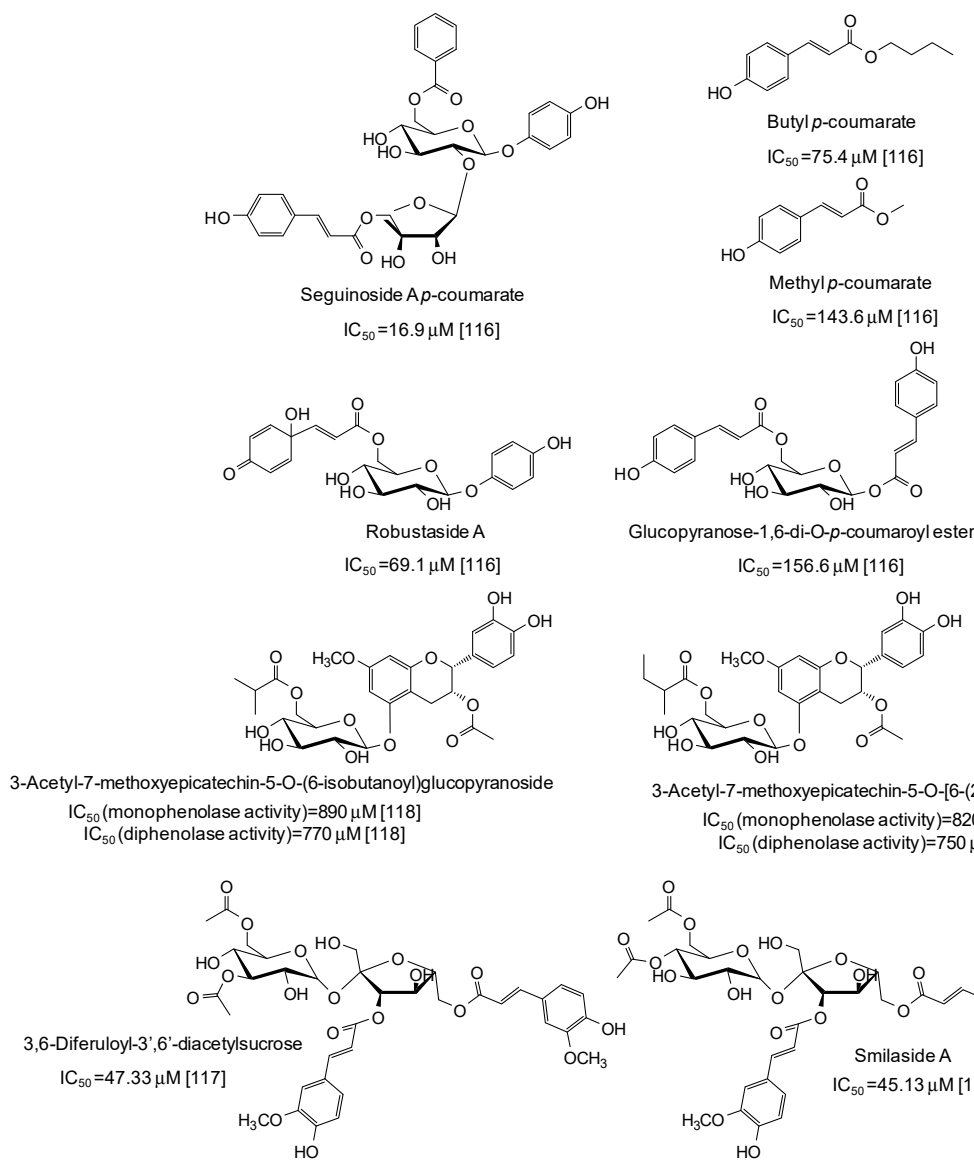
3-Acetyl-7-methoxyepicatechin-5-O-[6-(2-methylbutanoyl)]glucopyranoside
$\mathrm{IC}_{50}$ (monophenolase activity) $=820 \mu \mathrm{M}[118]$

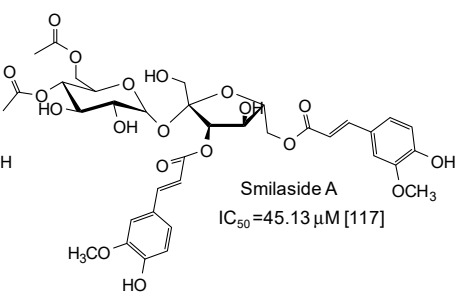

Figure 15. Chemical structures and $\mathrm{IC}_{50}$ values against mushroom tyrosinase of phenolic compounds isolated from Breynia and Oryza sativa species. Unless otherwise specified, $\mathrm{IC}_{50}$ values refer to the diphenolase activity of the enzyme.

Interestingly, polyamine derivatives comprising coumaroyl and caffeoyl moieties from bee pollen of Quercus mongolica have been also described as tyrosinase inhibitors [119].

Finally, moderate-high activity has been very recently reported for phenylethylchromones isolated from the agarwood of Aquilaria plants [120,121] and anthraquinones from Cassia tora seeds [122] (Figure 16).

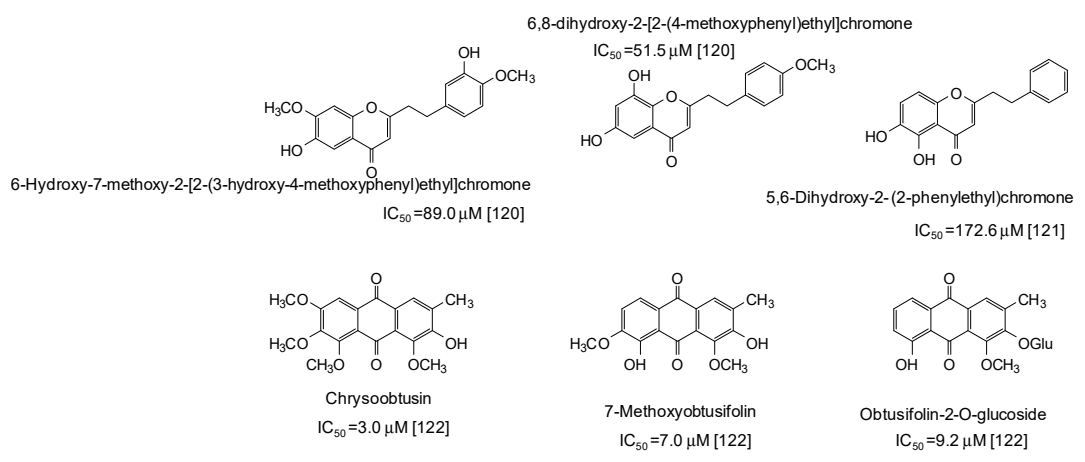

Figure 16. Chemical structures and IC50 values (referring to the diphenolase activity of the enzyme) against mushroom tyrosinase of phenolic compounds isolated from Aquilaria and Cassia tora species. 


\section{Synthetic Phenolic Inhibitors of Mushroom Tyrosinase}

In the last years several studies have been directed to the development of novel tyrosinase inhibitors inspired by natural scaffolds, which should overcome stability, efficacy, and isolation yield issues. One of the main exploited scaffolds is hydroxycinnamic acid: indeed several hydroxycinnamic acid analogues have been synthesized through the most disparate approaches [123-141], leading in some cases to very potent mushroom tyrosinase inhibitors (Figure 17), such as 2,4-dihydroxycinnamides $\left(\mathrm{IC}_{50}=0.0112-0.16 \mu \mathrm{M}\right)[132,133]$. A thiophenyl derivative of 2,4-dihydroxycinnamic acid has also exhibited a very low $\mathrm{IC}_{50}$ value $(0.013 \mu \mathrm{M})$ against the monophenolase activity of the enzyme [134]. An IC50 value of $1.10 \mu \mathrm{M}$ for the monophenolase activity of mushroom tyrosinase has been instead calculated for a cyclopentanone compound related to 3-hydroxy-4-methoxycinnamic acid [135]. Quite low $\mathrm{IC}_{50}$ values have been reported also for dihydrolipoic acid conjugates of caffeic acid and its methylester [136,137], as well as for thiochromanone compounds [138], diamides [139], or esters $[140,141]$ related to $p$-coumaric acid.

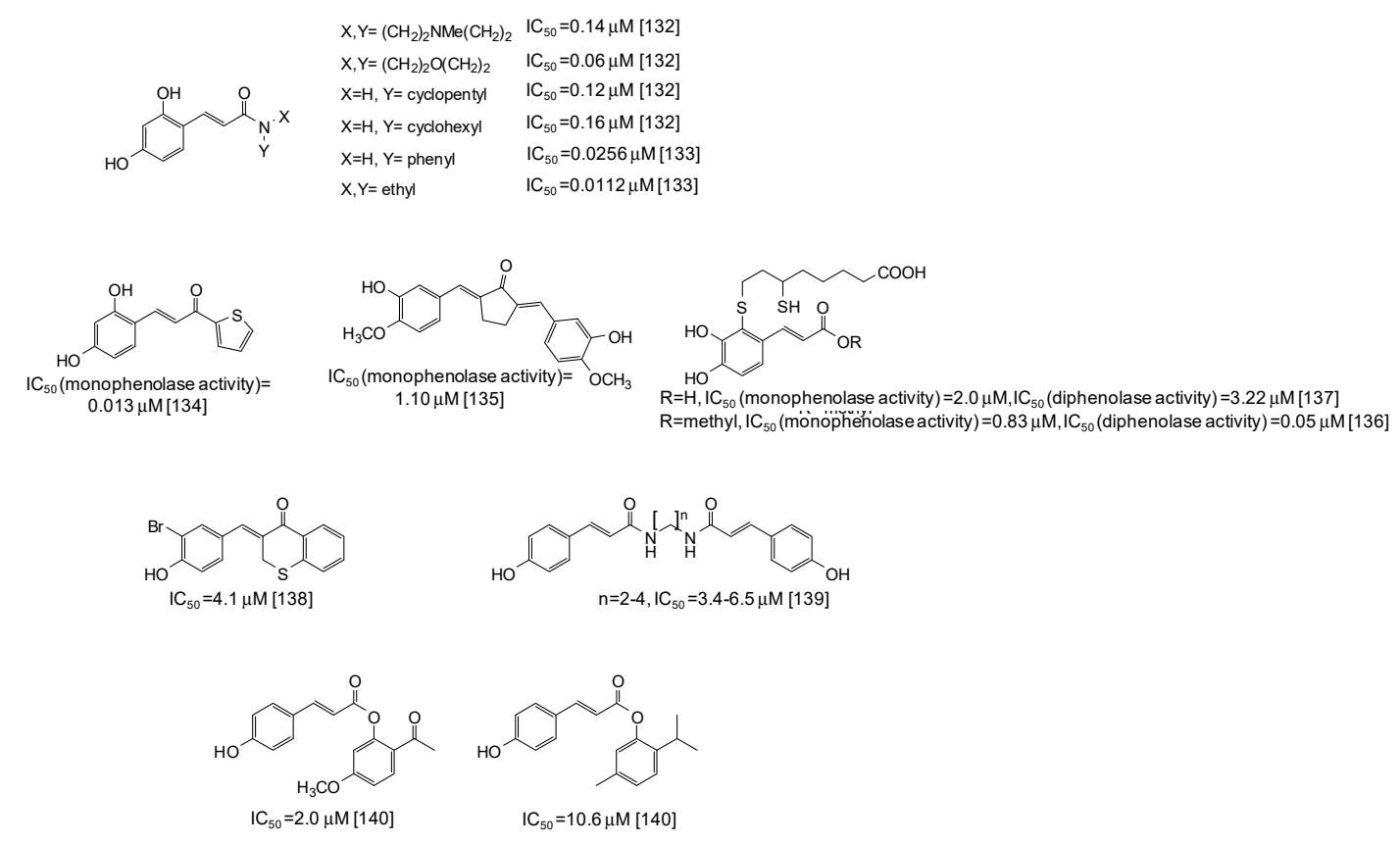

Figure 17. Chemical structures and $\mathrm{IC}_{50}$ values against mushroom tyrosinase of synthetic hydroxycinnamic acid derivatives. Unless otherwise specified, $\mathrm{IC}_{50}$ values refer to the diphenolase activity of the enzyme.

Similar scaffolds are chalcones [142-156], characterized by an enone moiety linked to a phenyl ring as well. Particularly active as mushroom tyrosinase inhibitors are 2,2', 4, $4^{\prime}$-tetrahydroxychalcone $\left(\mathrm{IC}_{50}=0.08 \mu \mathrm{M}\right)$ and its derivatives [149], followed by azachalcones $\left(\mathrm{IC}_{50}=1.70-2.30 \mu \mathrm{M}\right)$ [150], chalcone oximes $\left(\mathrm{IC}_{50}=4.5-8 \mu \mathrm{M}\right)$ [151], and a chalcone based pyrazoline $\left(\mathrm{IC}_{50}=4.72 \mu \mathrm{M}\right)$ [152] (Figure 18). Quite low $\mathrm{IC}_{50}$ values have been reported also for chalcone-21 $\left(\mathrm{IC}_{50}=6.8 \mu \mathrm{M}\right)$ [153], 6-methoxy-3,4-dihydronaphthalenone chalcone-like derivatives $\left(\mathrm{IC}_{50}=6.19 \mu \mathrm{M}\right)[154]$, aminochalcones [155], and indenone chalcone-like derivatives [156] (Figure 18). 

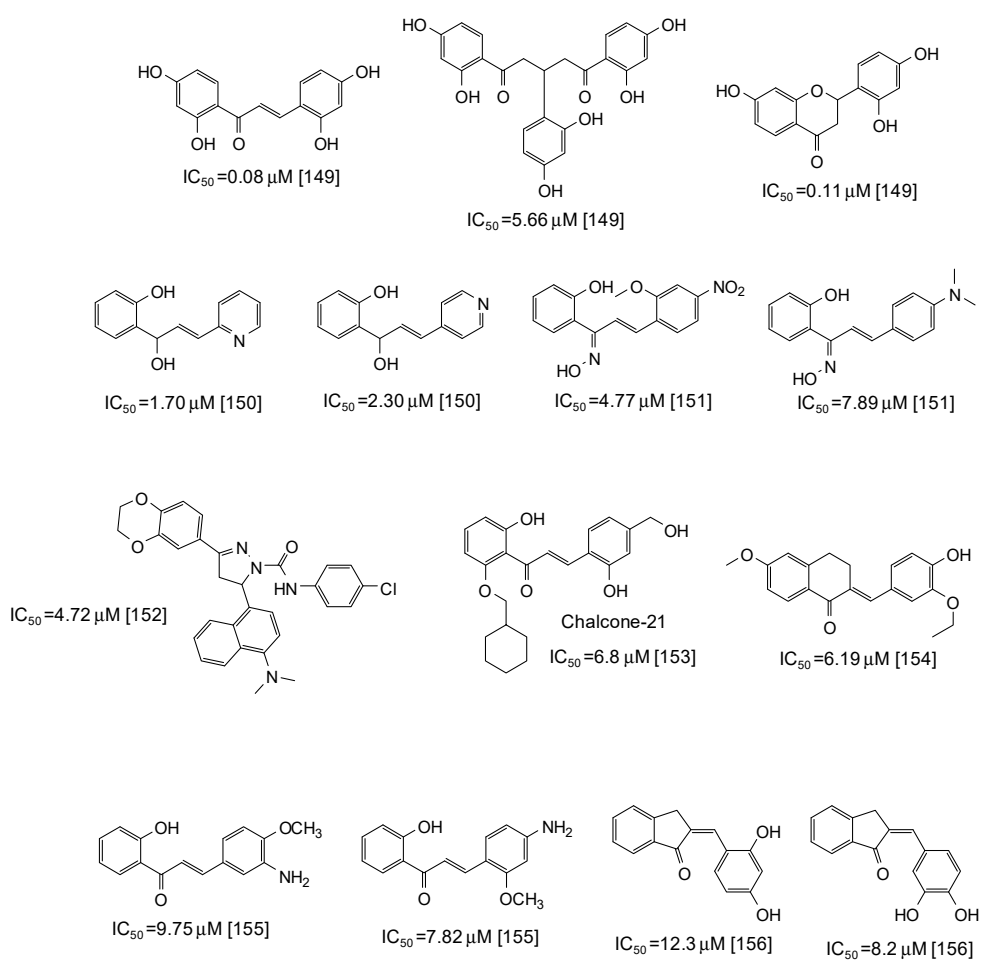

Figure 18. Chemical structures and $\mathrm{IC}_{50}$ values (referring to the diphenolase activity of the enzyme) against mushroom tyrosinase of synthetic chalcone derivatives.

As to other natural phenol-inspired synthetic compounds [157-161], the best results have been reported for a carvacrol derivative containing a 3,5-dihydroxyphenyl moiety $\left(\mathrm{IC}_{50}=0.0167 \mu \mathrm{M}\right)$ [159] (Figure 19). Good inhibition properties have been exhibited also by some rhododendrol glycosides $\left(\mathrm{IC}_{50}=0.56-9.15 \mu \mathrm{M}\right)[160]$ and eugenol derivatives $\left(\mathrm{IC}_{50}\right.$ ca. $\left.8 \mu \mathrm{M}\right)$ [161] (Figure 19).
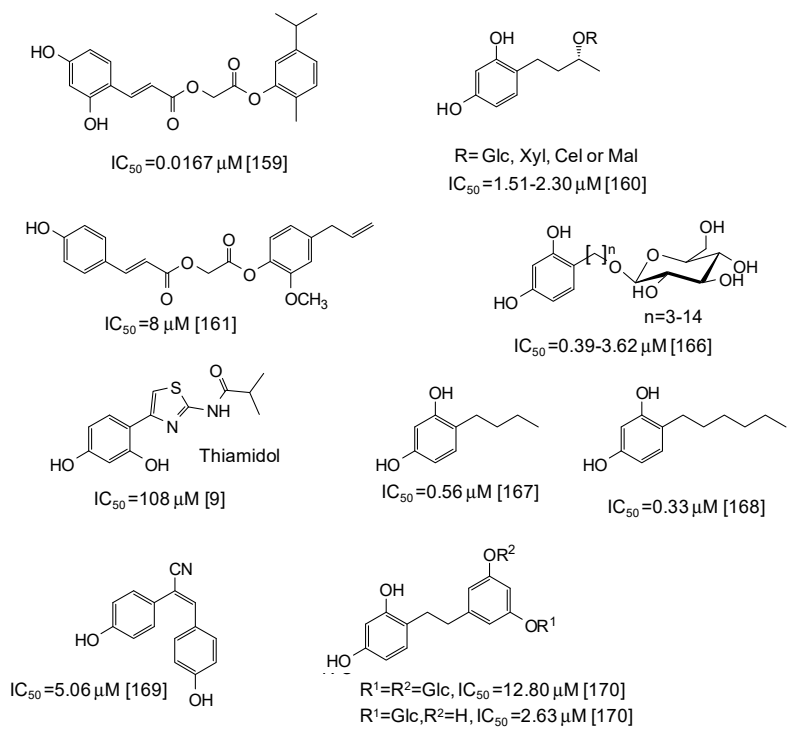

Figure 19. Chemical structures and $\mathrm{IC}_{50}$ values (referring to the diphenolase activity of the enzyme) against mushroom tyrosinase of synthetic phenolic compounds.

Of course, the most potent inhibitory activity is still attributed to resorcinol derivatives [162-170], although these compounds often suffer from toxicity concerns (the case of rhododendrol is emblematic [6-8]) (see below). Low $\mathrm{IC}_{50}$ values $(0.39-3.62 \mu \mathrm{M})$ have been reported for resorcinol 
alkyl glucosides [166] (Figure 19), whereas thiamidol, which is currently one of the most potent skin depigmenting agent on the market, is not so active against mushroom tyrosinase $\left(\mathrm{IC}_{50}=108 \mu \mathrm{M}\right)$ [9]. Alkyl resorcinols, such as 4-butylresorcinol or 4-hexylresorcinol, also exhibited very low $\mathrm{IC}_{50}$ values (Figure 19), particularly against the monophenolase activity $\left(\mathrm{IC}_{50}=0.077 \mu \mathrm{M}\right.$ for 4-butylresorcinol) $[167,168]$. Rather low $\mathrm{IC}_{50}$ values have been determined also for resveratrol derivatives such as (E)-2,3-bis(4-hydroxyphenyl)acrylonitrile $\left(\mathrm{IC}_{50}=5.06 \mu \mathrm{M}\right)[169]$ and dihydrooxyresveratrol glucosides [170] (Figure 19).

Coumarins are another class of compounds able to efficiently inhibit mushroom tyrosinase [171-174]. Coumarin dimers and derivatives containing a tetracyclic skeleton exhibited IC $_{50}$ values in the range 1.7-2.9 $\mu \mathrm{M}$ [172] (Figure 20), whereas even higher activity has been reported for synthetic 3-heteroarylcoumarins [173] and umbelliferone-thiazolidinedione hybrids [174] (Figure 20).

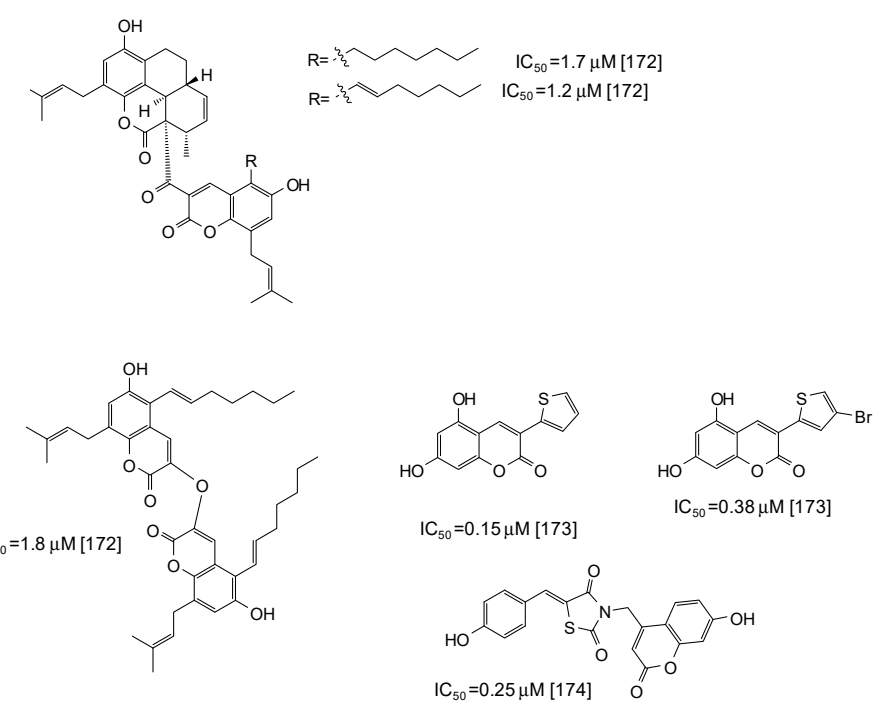

Figure 20. Chemical structures and $\mathrm{IC}_{50}$ values (referring to the diphenolase activity of the enzyme) against mushroom tyrosinase of synthetic coumarin derivatives.

\section{Human and Animal Tyrosinase Phenolic Inhibitors}

In the last five years, several natural and synthetic phenolic compounds have been described also as inhibitors of tyrosinase from animal and human sources. Most of these studies used B16 murine melanoma cell lines as a model $[52,55,75,85,95,96,99,114,122,123,127-129,132-135,138,139,151$, $153,155,163,175-205]$, although some papers using zebrafish as an in vivo whole animal model have also been published $[55,116,206]$. As to the human sources, data on inhibition of human recombinant or purified tyrosinase [9,207], human melanoma cells [130,136], normal human melanocytes [208-211], or human skin models consisting of reconstructed three-dimensional human epidermis [212-215] have been published (Figure 21). The results of clinical trials have also been reported for well recognized skin depigmenting agents $[216,217]$ such as thiamidol, that, as stated also above, is one of the most striking examples of a pigmentation inhibitor exhibiting significant higher activity on human than on mushroom tyrosinase $[9,218]$. This nicely exemplifies the differential effects of tyrosinase inhibitors on the human and mushroom enzymes, likely due to the presence of additional amino acids in the hydrophobic substrate-binding pocket of mushroom tyrosinase [218]. 


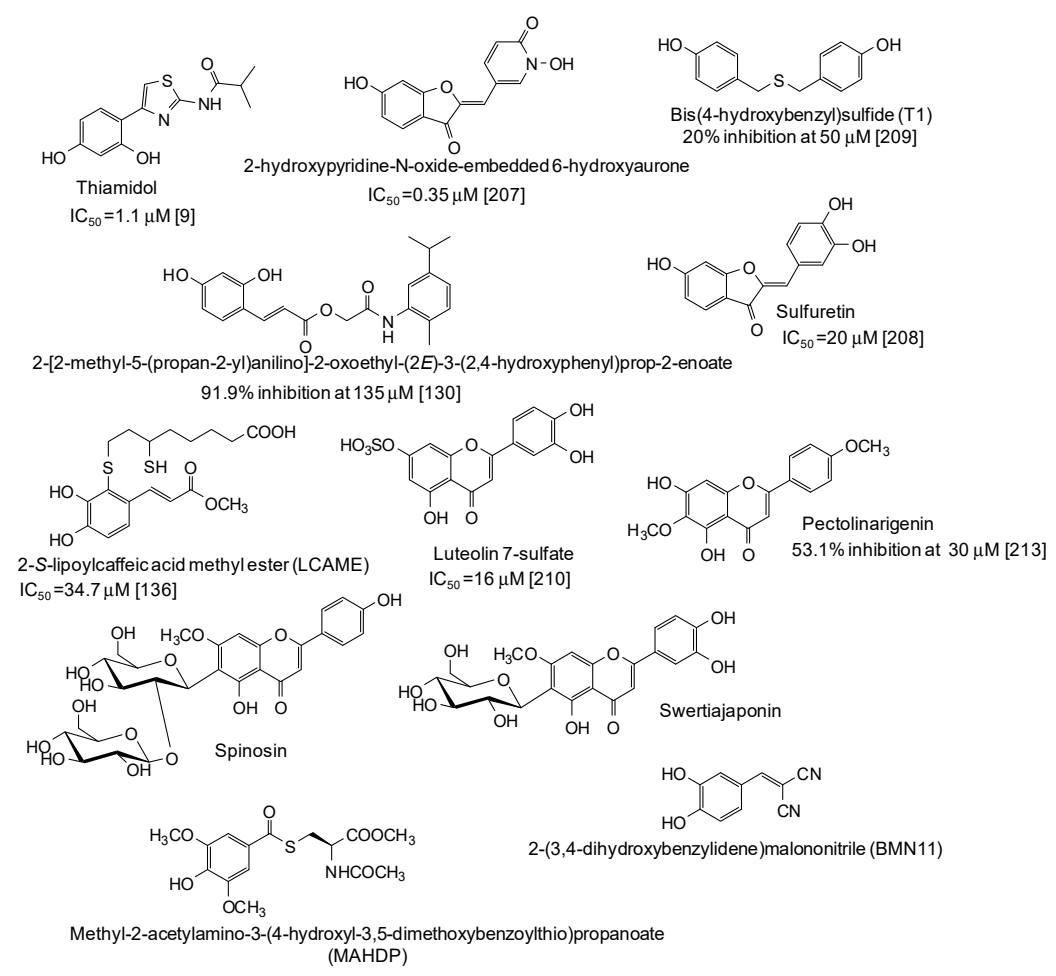

Figure 21. Chemical structures and inihibitory potency (where available) of the main human tyrosinase inhibitors.

Of course, care should be taken when cellular or in vivo models are considered, since several alternative or additional biochemical mechanisms can be operative, involving e.g., tyrosinase expression and interference with the complex signaling pathways in melanogenesis, which could result in melanin reduction as well. As an example, it has been reported that both ferulic and caffeic acid inhibited melanin production in B16 melanoma cells, but ferulic acid reduced tyrosinase activity by directly binding to the enzyme, whereas no binding was observed in the case of caffeic acid [177]. Apart from the direct inhibition of tyrosinase activity, the anti-melanogenic activity of resorcinol in B16F10 cells has been attributed to the inhibition of cAMP signaling and activation of p38 MAPK [179]. The same applies e.g., to moracin J [181], 4,5-dicaffeoylquinic acid [183], chrysin [187], casuarictin [178], and synthetic compounds [135,136,153,197], which have been reported to both inhibit intracellular tyrosinase activity and regulate melanogenesis-related protein expression.

In any case, there is no doubt that human tyrosinase inhibitors are really important in the perspective of cosmetics development.

\section{Structural Requirements for the Design of Tyrosinase Inhibitors}

Several inhibition mechanisms have been reported for the tyrosinase inhibitors described above, highlighting the importance of key structural moieties as responsible for the observed effects. As an example, in silico analysis showed that the flavonoids spinosin and swertiajaponin act as competitive inhibitors of the enzyme by binding to the active site through hydrogen bonding and hydrophobic interactions [212,214], as is the case also for condensed tannins from different sources based on molecular docking $[96,98,99]$. Chelation of copper ions by adjacent hydroxyl groups on the B ring has also been suggested as a feasible inhibition mechanism for proanthocyanidins $[101,102,106]$. Copper chelation as well as hydrophobic and hydrogen bonding within the active site resulting in secondary structural changes have been validated for brazilein, too [190]. Generally, the number and location of phenolic hydroxyl groups significantly affect the tyrosinase inhibitory activity in the case of flavonoids [62]. The presence of sugar moieties as well as the glycosylation pattern is also important: 
for example, flavanol containing 5-O- and 7-O-sugar moieties are more potent inhibitors compared to related not glycosylated compounds [118]. Interestingly, quercetin-3-O- $\alpha$-L-rhamnopyranoside possesses tyrosinase inhibition acitivity whereas 3-glycosylated flavonols were not active, suggesting that the rhamnosyl group at C-3 played an indispensable role in the anti-tyrosinase activity [59]. The impact of chemical structure on the tyrosinase inhibition properties is emblematic also in the case of hydroxystilbene compounds, in which the presence of the inter-ring double bond, or of methylated or glucosylated phenolic moieties strongly affect the $\mathrm{IC}_{50}$ value $[55,60,63]$.

The presence of the sulfur atom able to chelate the copper ions has been described as essential for the inhibitory activity in the case of bis(4-hydroxybenzyl) sulfide from Gastrodia elata [209].

An interaction driven mainly by electrostatic forces has instead been brought forth in the case of aloe-emodin, and this would induce changes in conformation of the enzyme preventing binding of the substrate [79]. Interactions with specific amino acid residues in the active site pocket of the enzyme have been evidenced by molecular dynamics simulation in the case of pyrogallol [77] and quercetin-7-O- $\alpha$-L-rhamnoside [182]. Binding via Met280 residue has been in particular predicted for baicalein [71]. In the case of obtusin derivatives, different interactions inside and/or outside the active site of the enzyme have been proposed [122].

Interactions with specific amino acids in the tyrosinase binding pocket has been predicted also for synthetic inhibitors, such as hydroxylated chalcone derivatives [151,155], 2-(3, 4-dihydroxybenzylidene) malononitrile [215], or carvacrol derivatives featuring a 2,4-dihydroxyphenyl moiety, able to interact with amino acid HIS85 through the 2-hydroxy group [159]. Other important structural requirements have been also underlined: for example, a three carbons tether with a diamide-link in dimeric cynnamoyl analogues is required to efficiently inhibit melanin production on $\alpha$-MSH stimulated B16F1 cells [139]. The same has been reported for the alkyl spacer in the case of resorcinol alkyl glucosides [166]. The presence of resorcinol and glucose moieties has also reported to be important [162]. Hydrogen bonds and aromatic (hydrophobic) interactions with tyrosinase have been predicted by docking simulation for the potent inhibitor MHY2081 [129].

\section{New Trends in the Search for Tyrosinase Inhibitors}

Recently, a rather large number of studies have been directed to the development of novel assays for the search and assessment of tyrosinase inhibitors. These have been prompted in part by the need to avoid interferences due to color development associated to the oxidation of phenolic compounds acting as substrates of mushroom tyrosinase [219,220].

As an example, a colorimetric assay based on a combination of chitosan-stabilized platinum nanoparticels, catechol, tyrosinase, and 3,3',5,5'-tetramethylbenzidine as the probe being oxidized to a yellow diamine has been proposed [221]. A microreactor-detector based on the use of a gold disk for tyrosinase immobilization and a carbon disk as a working electrode able to amperometrically detect dopaquinone formation starting from L-tyrosine has also been described [222]. Immobilized tyrosinase has been used also coupled to capillary electrophoresis [223,224].

A different approach is based on thin layer chromatography (TLC) bioautographic assay, with the reported advantages of a low cost and sensitive methodology [225], whereas ultrafiltration coupled with HPLC has been proposed as a strategy for identification of specific inhibitors of the enzyme [226].

The use of dopamine functionalized quantum dots exhibiting strong fluorescence undergoing quenching upon dopamine oxidation by the enzyme have also been proposed [227].

Alternatives to mushroom tyrosinase have also been developed, such as recombinant tyrosinase from Polyporus arcularius overproduced in Escherichia coli [228].

Perhaps one of the main drawbacks of the "classic" mushroom tyrosinase inhibition assay is that it does not enable to distinguish between skin whitening tyrosinase inhibitors and leukoderma inducing phenols, that is compounds which are readily oxidized by the enzyme leading to the generation of cytotoxic reactive quinones [229]. To this aim, a convenient screening method was reported, involving spectrophotometric monitoring of the incubation mixtures followed by reduction with $\mathrm{NaBH}_{4}$ and 
HPLC analysis. Under these conditions it was indeed possible to differentiate potential toxic enzyme substrates, such as rhododendrol, raspberry ketone, and $p$-susbstitued phenols, from tyrosinase inhibitors like ellagic acid [38].

Another issue to take into account is the possibility that the inhibitor compound may react with dopaquinone to give an adduct that is not further oxidized. In this way dopaquinone is subtracted from the melanogenic pathway and a decrease of pigmentation is observed though the activity of the enzyme that has not been affected to any extent. This could be the case of compounds comprising a resorcinol moiety [230], like phenylethyl resorcinol and resveratrol derivatives, or a thiazolidine unit that may undergo ring opening disclosing the thiol functionality [231]. Of course, the possible toxicity associated with the occurrence of this diverted reaction pathways should be carefully evaluated.

Another emerging research trend is the development of new formulations for improving the bioavaialability and hence the efficiency of tyrosinase inhibitors to be used as skin depigmenting agents. As an example, a polyethylene glycol/polycaprolactone (PEG/PCL) copolymer has shown good encapsulation efficiency toward the potent skin lightening agent adamantan-1-yl-N-(2,4-dihydroxybenzyl)-2,4-dimethoxybenzamide (known as AP736) [232]. On the same line, hybrid poly (lactic-co-glycolic acid) (PLGA) microspheres have been proposed to improve the encapsulation and control the release of amphiphilic compounds such as phenylethyl resorcinol, leading to $40 \%$ enhancement of tyrosinase inhibition in mouse melanoma cells [233]. Ethosomes formulations as well as nanostructured lipid carriers (NLCs) with high encapsulation efficiency and stability have also been developed for the delivery of phenylethyl resorcinol into the skin, exhibiting higher tyrosinase inhibition compared to other formulations in B16 melanoma cells [234,235]. Increased loading and chemical stability was achieved also by the use of smartPearls combined with the UV abosorber Tinosorb S [236].

SmartPearls consisting of mesoporus silica particles have been combined also with glabridin to enhance its water solubility by a factor higher than four and therefore improve its dermal bioavailability [237]. A 20-fold increase of tyrosinase inhibition activity has also been reported for a glabridin/hydroxypropyl- $\beta$-cyclodextrin inclusion complex [238].

Gallic acid-loaded cationic niosomes composed of Brij 52/cholesterol/cetyltrimethylammonium bromide at 7:3:0.65 have shown high stability and tyrosinase inhibition in B16F10 melanoma cells, due to controlled release of the phenol over $24 \mathrm{~h}$ [239].

Monoolein and lauroylcholine chloride-based vesicles have proven efficient at delivering 3-hydroyxcoumarin to the deeper skin layers [240]. NLCs as well as solid lipid nanoparticles (SLNs) have been employed instead for resveratrol encapsulation, enhancing its tyrosinase inhibitory activity [241,242] Good results have been obtained also with nanoparticles from calli of resveratrol-enriched rice [243].

SLNs for encapsulation of curcumin and a synthetic inhibitor, (Z)-5-(2,4-dihydroxy benzylidene)thiazolidine-2,4-dione (MHY498), have also been described [244,245].

Improved performance as a cosmetic ingredient has been finally reported for dextran-rosmarinic acid conjugates [246].

\section{Conclusions and Perspectives}

The regulation of melanogenesis is highly complex and a number of cellular factors are involved in this process. Tyrosinase, the central enzymatic system of melanogenesis, catalyzing the rate-limiting step of the pathway, has become one of the most important targets for the control of hyperpigmentary disorders of pathological or cosmetic relevance. As a result, in recent years, an impressive number of inhibitors have been reported that exert their action at the level of tyrosinase.

In general, given the availability and the ease of purification, tyrosinase from Agaricus bisporus mushroom is the most frequently used model for screening potential candidates in the development of skin-whitening substances, while human and mouse melanocytic lysates are used to a lesser extent. 
It is interesting to note that despite the diversity of natural inhibitors, a large number of tyrosinase inhibitors are phenolic in nature. Many researchers have designed appropriate scaffolds inspired by the structure of natural compounds and developed novel synthetic inhibitors. A valuable support in these studies has been provided by the molecular docking approach that allowed to rationalize the critical structural elements responsible for the inhibitory activity of natural compounds providing a guide for the design of more effective synthetic bioinspired inhibitors. In particular, from the survey of the recent literature reported in this paper the presence of at least one 2,4-dihydroxyphenyl (resorcinol) moiety stands as an essential factor to achieve effective tyrosinase inihibition properties. However, hydroxycinnamic acids possibily "activated" by suitable substituents are emerging as valid alternative depigmenting agents which, even though in most cases are of synthetic origin, should not, in principle, present toxicity issues associated with the entrapment of dopaquinone as briefly discussed in the previous paragraphs.

More in general, there are several issues that should be carefully considered in the development of the research in the field of tyrosinase inhibitors for the treatment of skin hyperpigmentation.

At present, though a wide range of tyrosinase inhibitors from natural and synthetic sources have been reported, only a few of them, in addition to being effective, are known as safe compounds. No significant advances concerning toxicity issues of tyrosinase inhibitors seem to emerge from the literature survey carried out for this review, the relevant papers just reporting the results of in vitro cytotoxicity experiments $[49,52,75,81,95,126,129,131-133,136,137,147,163,176-178,184,185,192,198,202$, $203,207,210,212,214,215,239,240,242,245]$ and only a few of in vivo experiments on zebrafish [130,206, 209]. Therefore, it is essential to examine the efficacy and safety of inhibitors by checking e.g., whether or not the candidate inhibitor is substrate of tyrosinase being modified on exposure to the enzyme. Once this first level of safety assessment has been passed, in vivo experiments using reconstructed three-dimensional human epidermis that has mostly replaced animal models tests should be carried out before the compound could be considered for clinical trials in the perspectives of its use in medicinal and cosmetic applications. Future directions of the research on pigmentation control by tyrosinase modulation also include the development of highly specific assays of the enzymatic activity as well as the appropriate use of innovative formulations for boosting the efficacy of the inhibitors by enhancing their bioavailability.

Supplementary Materials: The following are available online at http://www.mdpi.com/2079-9284/6/4/57/s1, Table S1: Main natural phenolic inhibitors of mushroom tyrosinase.

Author Contributions: L.P. and A.N. wrote the paper.

Funding: This research received no external funding.

Conflicts of Interest: The authors declare no conflict of interest.

\section{References}

1. Zolghadri, S.; Bahrami, A.; Hassan Khan, M.T.; Munoz-Munoz, J.; Garcia-Molina, F.; Garcia-Canovas, F.; Saboury, A.A. A comprehensive review on tyrosinase inhibitors. J. Enzyme Inhib. Med. Chem. 2019, 34, 279-309. [CrossRef] [PubMed]

2. Kumari, S.; Tien Guan Thng, S.; Kumar Verma, N.; Gautam, H.K. Melanogenesis inhibitors. Acta Dermatol. Venereol. 2018, 98, 924-931. [CrossRef] [PubMed]

3. Pillaiyar, T.; Namasivayam, V.; Manickam, M.; Jung, S.H. Inhibitors of melanogenesis: An updated review. J. Med. Chem. 2018, 61, 7395-7418. [CrossRef] [PubMed]

4. Gunia-Krzyżak, A.; Popiol, J.; Marona, H. Melanogenesis inhibitors: Strategies for searching for and evaluation of active compounds. Curr. Med. Chem. 2016, 23, 3548-3574. [CrossRef] [PubMed]

5. Lee, S.Y.; Baek, N.; Nam, T.G. Natural, semisynthetic and synthetic tyrosinase inhibitors. J. Enzyme Inhib. Med. Chem. 2016, 31, 1-13. [CrossRef] [PubMed]

6. Ito, S.; Wakamatsu, K. Biochemical mechanism of rhododendrol-induced leukoderma. Int. J. Mol. Sci. 2018, $19,552$. 
7. Gabe, Y.; Miyaji, A.; Kohno, M.; Hachiya, A.; Moriwaki, S.; Baba, T. Substantial evidence for the rhododendrol-induced generation of hydroxyl radicals that causes melanocyte cytotoxicity and induces chemical leukoderma. J. Dermatol. Sci. 2018, 91, 311-316. [CrossRef] [PubMed]

8. Abe, Y.; Okamura, K.; Kawaguchi, M.; Hozumi, Y.; Aoki, H.; Kunisada, T.; Ito, S.; Wakamatsu, K.; Matsunaga, K.; Suzuki, T. Rhododenol-induced leukoderma in a mouse model mimicking Japanese skin. J. Dermatol. Sci. 2016, 81, 35-43. [CrossRef]

9. Mann, T.; Gerwat, W.; Batzer, J.; Eggers, K.; Scherner, C.; Wenck, H.; Stäb, F.; Hearing, V.J.; Röhm, K.H.; Kolbe, L. Inhibition of human tyrosinase requires molecular motifs distinctively different from mushroom tyrosinase. J. Investig. Dermatol. 2018, 138, 1601-1608. [CrossRef]

10. Ito, S.; Wakamatsu, K.; d'Ischia, M.; Napolitano, A.; Pezzella, A. Structure of melanins. In Melanins and Melanosomes: Biosynthesis, Biogenesis, Physiological, and Pathological Functions; Riley, P.A., Borovansky, J., Eds.; Wiley-VCH: Weinheim, Germany, 2011; pp. 167-185.

11. Panzella, L.; Ebato, A.; Napolitano, A.; Koike, K. The late stages of melanogenesis: Exploring the chemical facets and the application opportunities. Int. J. Mol. Sci. 2018, 19, 1753. [CrossRef]

12. Serre, C.; Busuttil, V.; Botto, J.M. Intrinsic and extrinsic regulation of human skin melanogenesis and pigmentation. Int. J. Cosmet. Sci. 2018, 40, 328-347. [CrossRef] [PubMed]

13. Hurbain, I.; Romao, M.; Sextius, P.; Bourreau, E.; Marchal, C.; Bernerd, F.; Duval, C.; Raposo, G. Melanosome distribution in keratinocytes in different skin types: Melanosome clusters are not degradative organelles. J. Investig. Dermatol. 2018, 138, 647-656. [CrossRef] [PubMed]

14. Tadokoro, R.; Takahashi, Y. Intercellular transfer of organelles during body pigmentation. Curr. Opin. Genet. Dev. 2017, 45, 132-138. [CrossRef]

15. Thong, H.Y.; Jee, S.H.; Sun, C.C.; Boissy, R.E. The patterns of melanosome distribution in keratinocytes of human skin as one determining factor of skin colour. Br. J. Dermatol. 2003, 149, 498-505. [CrossRef] [PubMed]

16. Brenner, M.; Hearing, V.J. The protective role of melanin against UV damage in human skin. Photochem. Photobiol. 2008, 84, 539-549. [CrossRef]

17. Zubair, R.; Lyons, A.B.; Vellaichamy, G.; Peacock, A.; Hamzavi, I. What's new in pigmentary disorders. Dermatol. Clin. 2019, 37, 175-181. [CrossRef]

18. Maeda, K. Large melanosome complex is increased in keratinocytes of solar lentigo. Cosmetics 2017, 4, 49. [CrossRef]

19. Plensdorf, S.; Livieratos, M.; Dada, N. Pigmentation disorders: Diagnosis and management. Am. Fam. Physician 2017, 96, 797-804.

20. Ferreira Cestari, T.; Pinheiro Dantas, L.; Catucci Boza, J. Acquired hyperpigmentations. An. Bras. Dermatol. 2014, 89, 11-25. [CrossRef]

21. Yamaguchi, Y.; Hearing, V.J. Melanocytes and their diseases. Cold Spring Harb. Perspect. Med. 2014, 4, a017046. [CrossRef]

22. Cardinali, G.; Kovacs, D.; Picardo, M. Mechanisms underlying post-inflammatory hyperpigmentation: Lessons from solar lentigo. Ann. Dermatol. Venereol. 2012, 139, S148-S152. [CrossRef]

23. Raper, H.S. The tyrosinase-tyrosine reaction. Production from tyrosine of 5,6-dihydroxyindole and 5,6-dihydroxyindole-2-carboxylic acid-The precursors of melanin. Biochem. J. 1927, 21, 89-96. [CrossRef] [PubMed]

24. Mason, H.S. The chemistry of melanin. Mechanism of the oxidation of dihydroxyphenylalanine by tyrosinase. J. Biol. Chem. 1948, 172, 83-99. [PubMed]

25. Ito, S.; IFPCS. The IFPCS presidential lecture: A chemist's view of melanogenesis. Pigment Cell Res. 2003, 16, 230-236. [CrossRef] [PubMed]

26. Micillo, R.; Panzella, L.; Koike, K.; Monfrecola, G.; Napolitano, A.; d'Ischia, M. "Fifty shades" of black and red or how carboxyl groups fine tune eumelanin and pheomelanin properties. Int. J. Mol. Sci. 2016, 17, 746. [CrossRef] [PubMed]

27. Panzella, L.; Napolitano, A.; d'Ischia, M. Is DHICA the key to dopachrome tautomerase and melanocyte functions? Pigment Cell Melanoma Res. 2011, 24, 248-249. [CrossRef] [PubMed]

28. Jimenez-Cervantes, C.; Solano, F.; Kobayashi, T.; Urabe, K.; Hearing, V.J.; Lozano, J.A.; Garcia-Borron, J.C. A new enzymatic function in the melanogenic pathway. The 5,6-dihydroxyindole-2-carboxylic acid oxidase activity of tyrosinase related protein-1 (TRP1). J. Biol. Chem. 1994, 269, 17993-18001. [PubMed] 
29. Olivares, C.; Solano, F. New insights into the active site structure and catalytic mechanism of tyrosinase and its related proteins. Pigment Cell Melanoma Res. 2009, 22, 750-760. [CrossRef] [PubMed]

30. Niu, C.; Aisa, H.A. Upregulation of melanogenesis and tyrosinase activity: Potential agents for vitiligo. Molecules 2017, 22, 1303. [CrossRef] [PubMed]

31. Pillaiyar, T.; Manickam, M.; Namasivayam, V. Skin whitening agents: Medicinal chemistry perspective of tyrosinase inhibitors. J. Enzyme Inhib. Med. Chem. 2017, 32, 403-425. [CrossRef] [PubMed]

32. Solano, F. On the metal cofactor in the tyrosinase family. Int. J. Mol. Sci. 2018, 19, 633. [CrossRef] [PubMed]

33. Citek, C.; Lyons, C.T.; Wasinger, E.C.; Stack, T.D.P. Self-assembly of the oxy-tyrosinase core and the fundamental components of phenolic hydroxylation. Nat. Chem. 2012, 4, 317-322. [CrossRef] [PubMed]

34. Fujieda, N.; Yabuta, S.; Ikeda, T.; Oyama, T.; Muraki, N.; Kurisu, G.; Itoh, S. Crystal structures of copper-depleted and copper-bound fungal pro-tyrosinase: Insights into endogenous cysteine-dependent copper incorporation. J. Biol. Chem. 2013, 288, 22128-22140. [CrossRef] [PubMed]

35. Ramsden, C.A.; Riley, P.A. Tyrosinase: The four oxidation states of the active site and their relevance to enzymatic activation, oxidation and inactivation. Bioorg. Med. Chem. 2014, 15, 2388-2395. [CrossRef]

36. Hernández-Romero, D.; Sanchez-Amat, A.; Solano, F. A tyrosinase with an abnormally high tyrosine hydroxylase/dopa oxidase ratio. FEBS J. 2006, 273, 257-270. [CrossRef] [PubMed]

37. Vanitha, M.; Soundhari, C. Isolation and characterisation of mushroom tyrosinase and screening of herbal extracts for anti-tyrosinase activity. Int. J. ChemTech Res. 2017, 10, 1156-1167.

38. Ito, S.; Wakamatsu, K. A convenient screening method to differentiate phenolic skin whitening tyrosinase inhibitors from leukoderma-inducing phenols. J. Dermatol. Sci. 2015, 80, 18-24. [CrossRef]

39. Ioniţă, E.; Aprodu, I.; Stănciuc, N.; Râpeanu, G.; Bahrim, G. Advances in structure-function relationships of tyrosinase from Agaricus bisporus - Investigation on heat-induced conformational changes. Food Chem. 2014, 156, 129-136. [CrossRef]

40. Ismaya, W.T.; Tandrasasmita, O.M.; Sundari, S.; Diana; Lai, X.; Retnoningrum, D.S.; Dijkstra, B.W.; Tjandrawinata, R.R.; Rachmawati, H. The light subunit of mushroom Agaricus bisporus tyrosinase: Its biological characteristics and implications. Int. J. Biol. Macromol. 2017, 102, 308-314. [CrossRef]

41. Ismaya, W.T.; Rozeboom, H.J.; Weijn, A.; Mes, J.J.; Fusetti, F.; Wichers, H.J.; Dijkstra, B.W. Crystal structure of Agaricus bisporus mushroom tyrosinase: Identity of the tetramer subunits and interaction with tropolone. Biochemistry 2011, 50, 5477-5486. [CrossRef]

42. Bourquelot, E.; Bertrand, G. La laccase dans les champignons. Compt. Rendus. 1895, 121, 783-786.

43. Muñoz-Muñoz, J.L.; Garcia-Molina, F.; Varon, R.; Garcia-Ruíz, P.A.; Tudela, J.; Garcia-Cánovas, F.; Rodríguez-López, J.N. Suicide inactivation of the diphenolase and monophenolase activities of tyrosinase. IUBMB Life 2010, 62, 539-547. [CrossRef] [PubMed]

44. Haghbeen, K.; Saboury, A.A.; Karbassi, F. Substrate share in the suicide inactivation of mushroom tyrosinase. Biochim. Biophys. Acta 2004, 1675, 139-146. [CrossRef] [PubMed]

45. Land, E.J.; Ramsden, C.A.; Riley, P.A. The mechanism of suicide-inactivation of tyrosinase: A substrate structure investigation. Tohoku J. Exp. Med. 2007, 212, 341-348. [CrossRef] [PubMed]

46. Chang, T.S. An updated review of tyrosinase inhibitors. Int. J. Mol. Sci 2009, 10, 2440-2475. [CrossRef] [PubMed]

47. Solano, F.; Briganti, S.; Picardo, M.; Ghanem, G. Hypopigmenting agents: An updated review on biological, chemical and clinical aspects. Pigment Cell Res. 2006, 195, 550-571. [CrossRef] [PubMed]

48. Hamed, S.H.; Sriwiriyanont, P.; deLong, M.A.; Visscher, M.O.; Wickett, R.R.; Boissy, R.E. Comparative efficacy and safety of deoxyarbutin, a new tyrosinase inhibiting agent. J. Cosmet. Sci. 2006, 57, 291-308. [PubMed]

49. Tofani, R.P.; Sumirtapura, Y.C.; Darijanto, S.T. Formulation, characterisation, and in vitro skin diffusion of nanostructured lipid carriers for deoxyarbutin compared to a nanoemulsion and conventional cream. Sci. Pharm. 2016, 84, 634-645. [CrossRef] [PubMed]

50. Garcia-Jimenez, A.; Teruel-Puche, J.A.; Garcia-Ruiz, P.A.; Saura-Sanmartin, A.; Berna, J.; Garcia-Canovas, F.; Rodriguez-Lopez, J.N. Structural and kinetic considerations on the catalysis of deoxyarbutin by tyrosinase. PLoS ONE 2017, 12, e0187845. [CrossRef] [PubMed]

51. Zhang, L.; Tao, G.; Chen, J.; Zheng, Z.P. Characterization of a new flavone and tyrosinase inhibition constituents from the twigs of Morus Alba L. Molecules 2016, 21, 1130. [CrossRef] 
52. Chung, K.W.; Jeong, H.O.; Lee, E.K.; Kim, S.J.; Chun, P.; Chung, H.Y.; Moon, H.R. Evaluation of antimelanogenic activity and mechanism of galangin in silico and in vivo. Biol. Pharm. Bull. 2018, 41, 73-79. [CrossRef] [PubMed]

53. Morgan, A.M.A.; Jeon, M.N.; Jeong, M.H.; Yang, S.Y.; Kim, Y.H. Chemical components from the stems of Pueraria lobata and their tyrosinase inhibitory activity. Nat. Prod. Sci. 2016, 22, 111-116. [CrossRef]

54. Solimine, J.; Garo, E.; Wedler, J.; Rusanov, K.; Fertig, O.; Hamburger, M.; Atanassov, I.; Butterweck, V. Tyrosinase inhibitory constituents from a polyphenol enriched fraction of rose oil distillation wastewater. Fitoterapia 2016, 108, 13-19. [CrossRef] [PubMed]

55. Chaita, E.; Lambrinidis, G.; Cheimonidi, C.; Agalou, A.; Beis, D.; Trougakos, I.; Mikros, E.; Skaltsounis, A.L.; Aligiannis, N. Anti-melanogenic properties of Greek plants. A novel depigmenting agent from Morus alba wood. Molecules 2017, 22, 514. [CrossRef] [PubMed]

56. Tang, H.; Cui, F.; Li, H.; Huang, Q.; Li, Y. Understanding the inhibitory mechanism of tea polyphenols against tyrosinase using fluorescence spectroscopy, cyclic voltammetry, oximetry, and molecular simulations. RSC Adv. 2018, 8, 8310-8318. [CrossRef]

57. Renda, G.; Ozel, A.; Barut, B.; Korkmaz, B.; Soral, M.; Kandemir, U.; Liptaj, T. Bioassay guided isolation of active compounds from Alchemilla barbatiflora Juz. Rec. Nat. Prod. 2018, 12, 76-85. [CrossRef]

58. Lall, N.; Kishore, N.; Momtaz, S.; Hussein, A.; Naidoo, S.; Nqephe, M.; Crampton, B. Extract from Ceratonia siliqua exhibits depigmentation properties. Phytother. Res. 2015, 29, 1729-1736. [CrossRef] [PubMed]

59. Kakumu, Y.; Yamauchi, K.; Mitsunaga, T. Identification of chemical constituents from the bark of Larix kaempferi and their tyrosinase inhibitory effect. Holzforschung 2019, 73, 637-643. [CrossRef]

60. Uesugi, D.; Hamada, H.; Shimoda, K.; Kubota, N.; Ozaki, S.; Nagatani, N. Synthesis, oxygen radical absorbance capacity, and tyrosinase inhibitory activity of glycosides of resveratrol, pterostilbene, and pinostilbene. Biosci. Biotech. Biochem. 2017, 81, 226-230. [CrossRef] [PubMed]

61. Popova, I.E.; Morra, M.J. Sinapis alba seed meal as a feedstock for extracting the natural tyrosinase inhibitor 4-hydroxybenzyl alcohol. Ind. Crops Prod. 2018, 124, 505-509. [CrossRef]

62. Zuo, A.R.; Cao, S.W.; Zuo, A.R.; Dong, H.H.; Shu, Q.L.; Zheng, L.X.; Yu, X.Y.; Yu, Y.Y.; Cao, S.W. The antityrosinase and antioxidant activities of flavonoids dominated by the number and location of phenolic hydroxyl groups. Chin. Med. 2018, 13, 51. [CrossRef] [PubMed]

63. Hagiwara, K.; Okura, M.; Sumikawa, Y.; Hida, T.; Kuno, A.; Horio, Y.; Yamashita, T. Biochemical effects of the flavanol-rich lychee fruit extract on the melanin biosynthesis and reactive oxygen species. J. Dermatol. 2016, 43, 1174-1183. [CrossRef] [PubMed]

64. Pham, V.C.; Kim, O.; Lee, J.H.; Min, B.S.; Kim, J.A. Inhibitory effects of phloroglucinols from the roots of Dryopteris crassirhizoma on melanogenesis. Phytochem. Lett. 2017, 21, 51-56. [CrossRef]

65. Luyen, B.T.T.; Thao, N.P.; Widowati, W.; Fauziah, N.; Maesaroh, M.; Herlina, T.; Kim, Y.H. Chemical constituents of Piper aduncum and their inhibitory effects on soluble epoxide hydrolase and tyrosinase. Med. Chem. Res. 2017, 26, 220-226. [CrossRef]

66. Crespo, M.I.; Chaban, M.F.; Lanza, P.A.; Joray, M.B.; Palacios, S.M.; Vera, D.M.A.; Carpinella, M.C. Inhibitory effects of compounds isolated from Lepechinia meyenii on tyrosinase. Food Chem. Toxicol. 2019, 125, 383-391. [CrossRef] [PubMed]

67. Kishore, N.; Twilley, D.; Blom van Staden, A.; Verma, P.; Singh, B.; Cardinali, G.; Kovacs, D.; Picardo, M.; Kumar, V.; Lall, N. Isolation of flavonoids and flavonoid glycosides from Myrsine africana and their inhibitory activities against mushroom tyrosinase. J. Nat. Prod. 2018, 81, 49-56. [CrossRef]

68. Abed, S.A.; Sirat, H.M.; Taber, M. Tyrosinase inhibition, anti-acetylcholinesterase, and antimicrobial activities of the phytochemicals from Gynotroches axillaris Blume. Pak. J. Pharm. Sci. 2016, 29, 2071-2078. [PubMed]

69. Omar, S.H.; Scott, C.J.; Hamlin, A.S.; Obied, H.K. Biophenols: Enzymes ( $\beta$-secretase, cholinesterases, histone deacetylase and tyrosinase) inhibitors from olive (Olea europaea L.). Fitoterapia 2018, 128, 118-129. [CrossRef]

70. Kim, D.H.; Lee, J.H. Comparative evaluation of phenolic phytochemicals from perilla seeds of diverse species and screening for their tyrosinase inhibitory and antioxidant properties. S. Afr. J. Bot. 2019, 123, 341-350. [CrossRef]

71. Guo, N.; Wang, C.; Shang, C.; You, X.; Zhang, L.; Liu, W. Integrated study of the mechanism of tyrosinase inhibition by baicalein using kinetic, multispectroscopic and computational simulation analyses. Int. J. Biol. Macromol. 2018, 118, 57-68. [CrossRef] 
72. Shang, C.; Zhang, Y.; You, X.; Guo, N.; Wang, Y.; Fan, Y.; Liu, W. The effect of 7,8,4'-trihydroxyflavone on tyrosinase activity and conformation: Spectroscopy and docking studies. Luminescence 2018, 33, 681-691. [CrossRef] [PubMed]

73. Nguyen, H.X.; Nguyen, N.T.; Nguyen, M.H.K.; Le, T.H.; Do, T.N.V.; Hung, T.M.; Nguyen, M.T.T. Tyrosinase inhibitory activity of flavonoids from Artocarpus heterophyllous. Chem. Cent. J. 2016, 10, 2. [CrossRef] [PubMed]

74. Chen, J.; Liu, S.; Huang, Z.; Huang, W.; Li, Q.; Ye, Y. Molecular inhibitory mechanism of dihydromyricetin on mushroom tyrosinase. J. Biomol. Struct. Dyn. 2018, 36, 3740-3752. [CrossRef] [PubMed]

75. Ding, H.Y.; Chiang, C.M.; Tzeng, W.M.; Chang, T.S. Identification of $3^{\prime}$-hydroxygenistein as a potent melanogenesis inhibitor from biotransformation of genistein by recombinant Pichia pastoris. Process. Biochem. 2015, 50, 1614-1617. [CrossRef]

76. Casedas, G.; Les, F.; Gonzalez-Burgos, E.; Gomez-Serranillos, M.P.; Smith, C.; Lopez, V. Cyanidin-3-O-glucoside inhibits different enzymes involved in central nervous system pathologies and type-2 diabetes. S. Afr. J. Bot. 2019, 120, 241-246. [CrossRef]

77. Xiong, S.L.; Lim, G.T.; Yin, S.J.; Lee, J.; Si, Y.X.; Yang, J.M.; Park, Y.D.; Qian, G.Y. The inhibitory effect of pyrogallol on tyrosinase activity and structure: Integration study of inhibition kinetics with molecular dynamics simulation. Int. J. Biol. Macromol. 2019, 121, 463-471. [CrossRef] [PubMed]

78. Boghrati, Z.; Naseri, M.; Rezaie, M.; Pham, N.; Quinn, R.J.; Tayarani-Najaran, Z.; Iranshahi, M. Tyrosinase inhibitory properties of phenylpropanoid glycosides and flavonoids from Teucrium polium L. var. gnaphalodes. Iran. J. Basic Med. Sci. 2016, 19, 804-811.

79. Zeng, H.J.; Liu, Z.; Hu, G.Z.; Qu, L.B.; Yang, R. Investigation on the binding of aloe-emodin with tyrosinase by spectral analysis and molecular docking. Spectrochim. Acta Mol. Biomol. Spectrosc. 2019, 211, 79-85. [CrossRef] [PubMed]

80. Lu, T.M.; Ko, H.H. A new anthraquinone glycoside from Rhamnus nakaharai and anti-tyrosinase effect of 6-methoxysorigenin. Nat. Prod. Res. 2016, 30, 2655-2661. [CrossRef]

81. Kim, S.S.; Park, K.J.; JooAn, H.; Choi, Y.H. Inhibitory kinetics of enterolactone on mushroom tyrosinase. Der. Pharma Chem. 2016, 8, 124-130.

82. Magid, A.A.; Schmitt, M.; Prin, P.C.; Pasquier, L.; Voutquenne-Nazabadioko, L. In vitro tyrosinase inhibitory and antioxidant activities of extracts and constituents of Paeonia lactiflora Pall. flowers. Nat. Prod. J. 2017, 7, 237-245. [CrossRef]

83. Wang, Y.; Xu, L.Y.; Liu, X.; Feng, L.H.; Zhou, Z.W.; He, X.R.; Ren, G. Artopithecins A-D, prenylated 2-arylbenzofurans from the twigs of Artocarpus pithecogallus and their tyrosinase inhibitory activities. Chem. Pharm Bull. 2018, 66, 1199-1202. [CrossRef]

84. Abdullah, S.A.; Jamil, S.; Basar, N.; Abdul, L.; Siti, M.; Mohd Arriffin, N. Flavonoids from the leaves and heartwoods of Artocarpus lowii King and their bioactivities. Nat. Prod. Res. 2017, 31, 1113-1120. [CrossRef] [PubMed]

85. Jin, Y.J.; Lin, C.C.; Lu, T.M.; Li, J.H.; Chen, I.S.; Kuo, Y.H.; Ko, H.H. Chemical constituents derived from Artocarpus xanthocarpus as inhibitors of melanin biosynthesis. Phytochemistry 2015, 117, 424-435. [CrossRef]

86. Lathiff, S.M.A.; Jemaon, N.; Abdullah, S.A.; Jamil, S. Flavonoids from Artocarpus anisophyllus and their bioactivities. Nat. Prod. Commun. 2015, 10,393-396. [CrossRef]

87. Nguyen, M.T.T.; Le, T.H.; Nguyen, H.X.; Dang, P.H.; Do, T.N.V.; Abe, M.; Takagi, R.; Nguyen, N.T. Artocarmins G-M, prenylated 4-chromenones from the stems of Artocarpus rigida and their tyrosinase inhibitory activities. J. Nat. Prod. 2017, 80, 3172-3178. [CrossRef] [PubMed]

88. Duc, L.V.; Thanh, T.B.; Thu, H.L.T.; Bach, N.V. Chemical constituents and tyrosinase inhibitory activity of aqueous fraction of the leaves of Morus alba L. from Vietnam. Int. J. Pharmacogn. 2018, 5, 399-403.

89. Koirala, P.; Seong, S.H.; Zhou, Y.; Shrestha, S.; Jung, H.A.; Choi, J.S. Structure-activity relationship of the tyrosinase inhibitors kuwanon G, mulberrofuran G, and albanol B from Morus species: A kinetics and molecular docking study. Molecules 2018, 23, 1413. [CrossRef] [PubMed]

90. Xu, L.; Huang, C.; Wu, C.; Huang, T.; Jia, A.; Hu, X. Chiral separation, absolute configuration, and bioactivity of two pairs of flavonoid enantiomers from Morus nigra. Phytochemistry 2019, 16333-16337. [CrossRef] [PubMed]

91. Hu, X.; Yu, M.H.; Yan, G.R.; Wang, H.Y.; Hou, A.J.; Lei, C. Isoprenylated phenolic compounds with tyrosinase inhibition from Morus nigra. J. Asian Nat. Prod. Res. 2018, 20, 488-493. [CrossRef] 
92. Tian, J.L.; Liu, T.L.; Xue, J.J.; Hong, W.; Zhang, Y.; Zhang, D.X.; Cui, C.C.; Liu, M.C.; Niu, S.L. Flavanoids derivatives from the root bark of Broussonetia papyrifera as a tyrosinase inhibitor. Ind. Crops Prod. 2019, 138, 111445. [CrossRef]

93. Santi, M.D.; Peralta, M.A.; Mendoza, C.S.; Cabrera, J.L.; Ortega, M.G. Chemical and bioactivity of flavanones obtained from roots of Dalea pazensis Rusby. Bioorg. Med. Chem. Lett. 2017, 27, 1789-1794. [CrossRef] [PubMed]

94. Sabudak, T.; Ozturk, M.; Alpay, E. New bioflavonoids from Solanum nigrum L. by anticholinesterase and anti-tyrosinase activities-guided fractionation. Rec. Nat. Prod. 2017, 11, 130-140.

95. Promden, W.; Viriyabancha, W.; Monthakantirat, O.; Umehara, K.; Noguchi, H.; Umehara, K.; Noguchi, H.; De-Eknamkul, W. Correlation between the potency of flavonoids on mushroom tyrosinase inhibitory activity and melanin synthesis in melanocytes. Molecules 2018, 9, 1403. [CrossRef] [PubMed]

96. Chai, W.M.; Wei, Q.M.; Deng, W.L.; Zheng, Y.L.; Chen, X.Y.; Huang, Q.; Chong, O.Y.; Peng, Y.Y. Anti-melanogenesis properties of condensed tannins from Vigna angularis seeds with potent antioxidant and DNA damage protection activities. Food Funct. 2019, 10, 99-111. [CrossRef] [PubMed]

97. Chen, H.; Song, W.; Sun, K.K.; Du, H.W.; Wei, S.D. Structure elucidation and evaluation of antioxidant and tyrosinase inhibitory effect and mechanism of proanthocyanidins from leaf and fruit of Leucaena leucocephala. J. Wood Chem. Technol. 2018, 38, 430-444. [CrossRef]

98. Chai, W.M.; Ou-Yang, C.; Huang, Q.; Lin, M.Z.; Wang, Y.X.; Xu, K.L.; Huang, W.Y.; Pang, D.D. Antityrosinase and antioxidant properties of mung bean seed proanthocyanidins: Novel insights into the inhibitory mechanism. Food Chem. 2018, 260, 27-36. [CrossRef]

99. Chai, W.M.; Huang, Q.; Lin, M.Z.; Chong, O.Y.; Huang, W.Y.; Wang, Y.X.; Xu, K.L.; Feng, H.L. Condensed tannins from Longan bark as inhibitor of tyrosinase: Structure, activity, and mechanism. J. Agric. Food Chem. 2018, 66, 908-917. [CrossRef]

100. Song, W.; Qin, S.T.; Fang, F.X.; Gao, Z.J.; Liang, D.D.; Liu, L.L.; Tian, H.T.; Yang, H.B. Isolation and purification of condensed tannin from the leaves and branches of Prunus cerasifera and its structure and bioactivities. Appl. Biochem. Biotechnol. 2018, 185, 464-475. [CrossRef]

101. Chai, W.M.; Lin, M.Z.; Wang, Y.X.; Xu, K.L.; Huang, W.Y.; Pan, D.D.; Zou, Z.R.; Peng, Y.Y. Inhibition of tyrosinase by cherimoya pericarp proanthocyanidins: Structural characterization, inhibitory activity and mechanism. Food Res. Int. 2017, 100, 731-739. [CrossRef]

102. Chai, W.M.; Lin, M.Z.; Feng, H.L.; Zou, Z.R.; Wang, Y.X. Proanthocyanidins purified from fruit pericarp of Clausena lansium (Lour.) Skeels as efficient tyrosinase inhibitors: Structure evaluation, inhibitory activity and molecular mechanism. Food Funct. 2017, 8, 1043-1051. [CrossRef] [PubMed]

103. Song, W.; Zhu, X.F.; Ding, X.D.; Yang, H.B.; Qin, S.T.; Chen, H.; Wei, S.D. Structural features, antioxidant and tyrosinase inhibitory activities of proanthocyanidins in leaves of two tea cultivars. Int. J. Food Prop. 2017, 20, 1348-1358. [CrossRef]

104. Deng, Y.T.; Liang, G.; Shi, Y.; Li, H.L.; Zhang, J.; Mao, X.M.; Fu, Q.R.; Peng, W.X.; Chen, Q.X.; Shen, D.Y. Condensed tannins from Ficus altissima leaves: Structural, antioxidant, and antityrosinase properties. Process. Biochem. 2016, 51, 1092-1099. [CrossRef]

105. Chai, W.M.; Wang, R.; Wei, M.K.; Zou, Z.R.; Deng, R.G.; Liu, W.S.; Peng, Y.Y. Proanthocyanidins extracted from Rhododendron pulchrum leaves as source of tyrosinase inhibitors: Structure, activity, and mechanism. PLoS ONE 2015, 10, e0145483. [CrossRef] [PubMed]

106. Chai, W.M.; Wei, M.K.; Wang, R.; Deng, R.G.; Zou, Z.R.; Peng, Y.Y. Avocado proanthocyanidins as a source of tyrosinase inhibitors: Structure characterization, inhibitory activity, and mechanism. J. Agric. Food Chem. 2015, 63, 7381-7387. [CrossRef]

107. Gong, C.F.; Wang, Y.X.; Wang, M.L.; Su, W.C.; Wang, Q.; Chen, Q.X.; Shi, Y. Evaluation of the structure and biological activities of condensed tannins from Acanthus ilicifolius Linn and their effect on fresh-cut fuji apples. Appl. Biochem. Biotechnol. 2019. [CrossRef] [PubMed]

108. Lin, Y.; Kuang, Y.; Li, K.; Wang, S.; Song, W.; Qiao, X.; Sabir, G.; Ye, M. Screening for bioactive natural products from a 67-compound library of Glycyrrhiza inflate. Bioorg. Med. Chem. 2017, 25, 3706-3713. [CrossRef]

109. Li, K.; Ji, S.; Song, W.; Kuang, Y.; Lin, Y.; Tang, S.; Cui, Z.; Qiao, X.; Yu, S.; Ye, M. Glycybridins A-K, bioactive phenolic compounds from Glycyrrhiza glabra. J. Nat. Prod. 2017, 80, 334-346. [CrossRef] 
110. Ji, S.; Li, Z.; Song, W.; Wang, Y.; Liang, W.; Li, K.; Tang, S.; Wang, Q.; Qiao, X.; Zhou, D.; et al. Bioactive constituents of Glycyrrhiza uralensis (licorice): Discovery of the effective components of a traditional herbal medicine. J. Nat. Prod. 2016, 79, 281-292. [CrossRef]

111. Tao, Y.; Su, D.; Du, Y.; Li, W.; Cai, B.; Di, L.; Shi, L.; Hu, L. Magnetic solid-phase extraction coupled with HPLC-Q-TOF-MS for rapid analysis of tyrosinase binders from San-Bai decoction by Box-Behnken statistical design. RSC Adv. 2016, 6, 109730-109741. [CrossRef]

112. Magid, A.A.; Abdellah, A.; Pecher, V.; Pasquier, L.; Harakat, D.; Voutquenne-Nazabadioko, L. Flavonol glycosides and lignans from the leaves of Opilia amentacea. Phytochem. Lett. 2017, 21, 84-89. [CrossRef]

113. Kim, J.Y.; Kim, J.Y.; Jenis, J.; Li, Z.P.; Ban, Y.J.; Baiseitova, A.; Park, K.H. Tyrosinase inhibitory study of flavonolignans from the seeds of Silybum marianum (Milk thistle). Bioorg. Med. Chem. 2019, 27, 2499-2507. [CrossRef] [PubMed]

114. Setyawati, A.; Hirabayashi, K.; Yamauchi, K.; Hattori, H.; Mitsunaga, T.; Batubara, I.; Heryanto, R.; Hashimoto, H.; Hotta, M. Melanogenesis inhibitory activity of components from Salam leaf (Syzygium polyanthum) extract. J. Nat. Med. 2018, 72, 474-480. [CrossRef] [PubMed]

115. Kim, D.W.; Woo, H.S.; Kim, J.Y.; Ryuk, J.A.; Park, K.H.; Ko, B.S. Phenols displaying tyrosinase inhibition from Humulus lupulus. J. Enzyme Inhib. Med. Chem. 2016, 31, 742-747. [PubMed]

116. Sasaki, A.; Yamano, Y.; Sugimoto, S.; Otsuka, H.; Matsunami, K.; Shinzato, T. Phenolic compounds from the leaves of Breynia officinalis and their tyrosinase and melanogenesis inhibitory activities. J. Nat. Med. 2018, 72, 381-389. [CrossRef] [PubMed]

117. Cho, J.G.; Cha, B.J.; Seo, W.D.; Jeong, R.H.; Shrestha, S.; Kim, J.Y.; Kang, H.C.; Baek, N.I. Feruloyl sucrose esters from Oryza sativa roots and their tyrosinase inhibition activity. Chem. Nat. Compd. 2015, 51, 1094-1098. [CrossRef]

118. Peng, W.W.; Wang, Z.Q.; Ji, M.Y.; Liao, Z.L.; Liu, Z.Q.; Wu, P. Tyrosinase inhibitory activity of three new glycosides from Breynia fruticosa. Phytochem. Lett. 2017, 22, 1-5. [CrossRef]

119. Kim, S.B.; Liu, Q.; Ahn, J.H.; Jo, Y.H.; Turk, A.; Hong, I.P.; Han, S.M.; Hwang, B.Y.; Lee, M.K. Polyamine derivatives from the bee pollen of Quercus mongolica with tyrosinase inhibitory activity. Bioorg. Chem. 2018, 81, 127-133. [CrossRef]

120. Yang, L.; Yang, Y.L.; Dong, W.H.; Li, W.; Wang, P.; Cao, X.; Yuan, J.Z.; Chen, H.Q.; Mei, W.L.; Dai, H.F. Sesquiterpenoids and 2-(2-phenylethyl)chromones respectively acting as $\alpha$-glucosidase and tyrosinase inhibitors from agarwood of an Aquilaria plant. J. Enzyme Inhib. Med. Chem. 2019, 34, 853-862. [CrossRef] [PubMed]

121. Zhao, Y.M.; Yang, L.; Dong, W.H.; Li, W.; Chen, H.Q.; Wang, H.; Cai, C.H.; Gai, C.J.; Mei, W.L.; Dai, H.F. Three new 2-(2-phenylethyl)chromone derivatives from agarwood of Aquilaria crassna Pierre ex Lecomte (Thymelaeaceae) in Laos. Phytochem. Lett. 2019, 32, 134-137. [CrossRef]

122. Lee, G.Y.; Cho, B.O.; Shin, J.Y.; Jang, S.I.; Cho, I.S.; Kim, H.Y.; Park, J.S.; Cho, C.W.; Kang, J.S.; Kim, J.H.; et al. Tyrosinase inhibitory components from the seeds of Cassia tora. Arch. Pharm. Res. 2018, 41, 490-496. [CrossRef] [PubMed]

123. Ullah, S.; Park, Y.; Park, C.; Lee, S.; Kang, D.; Yang, J.; Akter, J.; Chun, P.; Moon, H.R. Antioxidant, anti-tyrosinase and anti-melanogenic effects of (E)-2,3-diphenylacrylic acid derivatives. Bioorg. Med. Chem. 2019, 27, 2192-2200. [CrossRef] [PubMed]

124. Gur, Z.T.; Senol, F.S.; Shekfeh, S.; Orhan, I.E.; Banoglu, E.; Caliskan, B. Novel piperazine amides of cinnamic acid derivatives as tyrosinase inhibitors. Lett. Drug Des. Discov. 2019, 16, 36-44. [CrossRef]

125. Kim, S.J.; Yang, J.; Lee, S.; Park, C.; Kang, D.; Akter, J.; Ullah, S.; Kim, Y.J.; Chun, P.; Moon, H.R. The tyrosinase inhibitory effects of isoxazolone derivatives with a (Z)- $\beta$-phenyl- $\alpha, \beta$-unsaturated carbonyl scaffold. Bioorg. Med. Chem. 2018, 26, 3882-3889. [CrossRef] [PubMed]

126. Yang, J.K.; Lee, E.; Hwang, I.J.; Yim, D.B.; Han, J.; Lee, Y.S.; Kim, J.H. $\beta$-Lactoglobulin peptide fragments conjugated with caffeic acid displaying dual activities for tyrosinase inhibition and antioxidant effect. Bioconjugate Chem. 2018, 29, 1000-1005. [CrossRef] [PubMed]

127. Jung, H.J.; Lee, M.J.; Park, Y.J.; Noh, S.G.; Lee, A.K.; Moon, K.M.; Lee, E.K.; Bang, E.J.; Park, Y.J.; Kim, S.J.; et al. A novel synthetic compound, (Z)-5-(3-hydroxy-4-methoxybenzylidene)-2-iminothiazolidin-4-one (MHY773) inhibits mushroom tyrosinase. Biosci. Biotech. Biochem. 2018, 82, 759-767. [CrossRef] [PubMed] 
128. Bang, E.; Lee, E.K.; Noh, S.G.; Jung, H.J.; Moon, K.M.; Park, M.H.; Park, Y.J.; Hyun, M.K.; Lee, A.K.; Kim, S.J.; et al. In vitro and in vivo evidence of tyrosinase inhibitory activity of a synthesized (Z)-5-(3-hydroxy-4-methoxybenzylidene)-2-thioxothiazolidin-4-one (5-HMT). Exp. Dermatol. 2019, 28, 734-737. [CrossRef] [PubMed]

129. Kang, K.H.; Lee, B.; Son, S.; Yun, H.Y.; Moon, K.M.; Jeong, H.O.; Kim, D.H.; Lee, E.K.; Choi, Y.J.; Kim, D.H.; et al. (Z)-2-(Benzo[d]thiazol-2-ylamino)-5-(substituted benzylidene)thiazol-4(5H)-one derivatives as novel tyrosinase inhibitors. Biol. Pharm. Bull. 2015, 38, 1227-1233. [CrossRef]

130. Abbas, Q.; Ashraf, Z.; Hassan, M.; Nadeem, H.; Latif, M.; Afzal, S.; Seo, S.Y. Development of highly potent melanogenesis inhibitor by in vitro, in vivo and computational studies. Drug Des. Devel. Ther. 2017, 11, 2029-2046. [CrossRef] [PubMed]

131. Ashraf, Z.; Rafiq, M.; Seo, S.Y.; Babar, M.M.; Zaidi, N.U. Synthesis, kinetic mechanism and docking studies of vanillin derivatives as inhibitors of mushroom tyrosinase. Bioorg. Med. Chem. 2015, 23, 5870-5880. [CrossRef]

132. Ullah, S.; Park, C.; Ikram, M.; Kang, D.; Lee, S.; Yang, J.; Park, Y.; Yoon, S.; Chun, P.; Moon, H.R. Tyrosinase inhibition and anti-melanin generation effect of cinnamamide analogues. Bioorg. Chem. 2019, 87, 43-55. [CrossRef] [PubMed]

133. Ullah, S.; Kang, D.; Lee, S.; Ikram, M.; Park, C.; Park, Y.; Yoon, S.; Chun, P.; Moon, H.R. Synthesis of cinnamic amide derivatives and their anti-melanogenic effect in $\alpha$-MSH-stimulated B16F10 melanoma cells. Eur. J. Med. Chem. 2019, 161, 78-92. [CrossRef] [PubMed]

134. Kim, C.S.; Noh, S.G.; Park, Y.; Kang, D.; Chun, P.; Chung, H.Y.; Jung, H.J.; Moon, H.R. A potent tyrosinase inhibitor, (E)-3-(2,4-dihydroxyphenyl)-1-(thiophen-2-yl)prop-2-en-1-one, with anti-melanogenesis properties in $\alpha$-MSH and IBMX-induced B16F10 melanoma cells. Molecules 2018, 23, 2725. [CrossRef] [PubMed]

135. Jung, H.J.; Lee, A.K.; Park, Y.J.; Lee, S.; Kang, D.; Jung, Y.S.; Chung, H.Y.; Moon, H.R. (2E,5E)-2,5-Bis(3-hydroxy-4-methoxybenzylidene) cyclopentanone exerts anti-melanogenesis and anti-wrinkle activities in B16F10 melanoma and Hs27 fibroblast cells. Molecules 2018, 23, 1415. [CrossRef] [PubMed]

136. Micillo, R.; Sires-Campos, J.; Garcia-Borron, J.C.; Panzella, L.; Napolitano, A.; Olivares, C. Conjugation with dihydrolipoic acid imparts caffeic acid ester potent inhibitory effect on dopa oxidase activity of human tyrosinase. Int. J. Mol. Sci. 2018, 19, 2156. [CrossRef]

137. Micillo, R.; Pistorio, V.; Pizzo, E.; Panzella, L.; Napolitano, A.; d'Ischia, M. 2-S-lipoylcaffeic acid, a natural product-based entry to tyrosinase inhibition via catechol manipulation. Biomimetics 2017, 2, 15. [CrossRef]

138. Bang, E.; Noh, S.G.; Ha, S.; Jung, H.J.; Kim, D.H.; Lee, A.K.; Hyun, M.K.; Kang, D.; Lee, S.; Park, C.; et al. Evaluation of the novel synthetic tyrosinase inhibitor (Z)-3-(3-bromo-4-hydroxybenzylidene) thiochroman-4-one (MHY1498) in vitro and in silico. Molecules 2018, 23, 3307. [CrossRef]

139. Ha, J.H.; Park, S.N. Dimeric cinnamoylamide analogues for regulation of tyrosinase activity in melanoma cells: A role of diamide-link chain length. Bioorg. Med. Chem. 2018, 26, 6015-6022. [CrossRef]

140. Sheng, Z.; Ge, S.; Xu, X.; Zhang, Y.; Wu, P.; Zhang, K.; Xu, X.; Li, C.; Zhao, D.; Tang, X. Design, synthesis and evaluation of cinnamic acid ester derivatives as mushroom tyrosinase inhibitors. Medchemcomm 2018, 9, 853-861. [CrossRef]

141. Sheng, Z.; Ge, S.; Xu, X.; Zhang, Y.; Wu, P.; Zhang, K.; Xu, X.; Li, C.; Zhao, D.; Tang, X. Correction: Design, synthesis and evaluation of cinnamic acid ester derivatives as mushroom tyrosinase inhibitors. Medchemcomm 2018, 9, 897. [CrossRef]

142. Aliabadi, R.S.; Mahmoodi, N.O.; Ghafoori, H.; Roohi, H.; Pourghasem, V. Design and synthesis of novel bis-hydroxychalcones with consideration of their biological activities. Res. Chem. Intermediat. 2018, 44, 2999-3015. [CrossRef]

143. Suthar, S.K.; Bansal, S.; Narkhede, N.; Guleria, M.; Alex, A.T.; Joseph, A. Design, synthesis and biological evaluation of oxindole-based chalcones as small-molecule inhibitors of melanogenic tyrosinase. Chem. Pharm. Bull. 2017, 65, 833-839. [CrossRef] [PubMed]

144. Radhakrishnan, S.K.; Shimmon, R.G.; Conn, C.; Baker, A.T. Inhibitory kinetics of azachalcones and their oximes on mushroom tyrosinase: A facile solid-state synthesis. Chem. Biodivers. 2016, 13, 531-538. [CrossRef] [PubMed]

145. Radhakrishnan, S.; Shimmon, R.; Conn, C.; Baker, A. Development of hydroxylated naphthylchalcones as polyphenol oxidase inhibitors: Synthesis, biochemistry and molecular docking studies. Bioorg. Chem. 2015, 63, 116-122. [CrossRef] [PubMed] 
146. Radhakrishnan, S.; Shimmon, R.; Conn, C.; Baker, A. Integrated kinetic studies and computational analysis on naphthyl chalcones as mushroom tyrosinase inhibitors. Bioorg. Med. Chem. Lett. 2015, 25, 4085-4091. [CrossRef] [PubMed]

147. Suthar, S.K.; Aggarwal, V.; Chauhan, M.; Sharma, A.; Bansal, S.; Sharma, M. Molecular docking and biological evaluation of hydroxy-substituted (Z)-3-benzylideneindolin-2-one chalcones for the lead identification as tyrosinase inhibitors. Med. Chem. Res. 2015, 24, 1331-1341. [CrossRef]

148. Zheng, Z.P.; Zhang, Y.N.; Zhang, S.; Chen, J. One-pot green synthesis of 1,3,5-triarylpentane-1,5-dione and triarylmethane derivatives as a new class of tyrosinase inhibitors. Bioorg. Med. Chem. Lett. 2016, 26, 795-798. [CrossRef] [PubMed]

149. Dong, X.; Zhang, Y.; He, J.L.; Zhang, S.; Zeng, M.M.; Chen, J.; Zheng, Z.P. Preparation of tyrosinase inhibitors and antibrowning agents using green technology. Food Chem. 2016, 197, 589-596. [CrossRef]

150. Radhakrishnan, S.K.; Shimmon, R.G.; Conn, C.; Baker, A.T. Azachalcones: A new class of potent polyphenol oxidase inhibitors. Bioorg. Med. Chem. Lett. 2015, 25, 1753-1756. [CrossRef] [PubMed]

151. Radhakrishnan, S.K.; Shimmon, R.G.; Conn, C.; Baker, A.T. Evaluation of novel chalcone oximes as inhibitors of tyrosinase and melanin formation in B16 cells. Archiv der Pharmazie 2016, 349, 20-29. [CrossRef]

152. Qin, H.L.; Shang, Z.P.; Jantan, I.; Tan, O.U.; Hussain, M.A.; Sher, M.; Bukhari, S.N.A. Molecular docking studies and biological evaluation of chalcone based pyrazolines as tyrosinase inhibitors and potential anticancer agents. RSC Adv. 2015, 5, 46330-46338. [CrossRef]

153. Kim, B.H.; Park, K.C.; Park, J.H.; Lee, C.G.; Ye, S.K.; Park, J.Y. Inhibition of tyrosinase activity and melanin production by the chalcone derivative 1-(2-cyclohexylmethoxy-6-hydroxy-phenyl)-3-(4-hydroxymethylphenyl)-propenone. Biochem. Biophys. Res. Commun. 2016, 480, 648-654. [CrossRef] [PubMed]

154. Ranjbar, S.; Akbari, A.; Edraki, N.; Khoshneviszadeh, M.; Hemmatian, H.; Firuzi, O.; Khoshneviszadeh, M. 6-Methoxy-3,4-dihydronaphthalenone chalcone-like derivatives as potent tyrosinase inhibitors and radical scavengers. Lett. Drug Des. Discov. 2018, 15, 1170-1179. [CrossRef]

155. Radhakrishnan, S.; Shimmon, R.; Conn, C.; Baker, A. Design, synthesis and biological evaluation of hydroxy substituted amino chalcone compounds for antityrosinase activity in B16 cells. Bioorg. Chem. 2015, 62, 117-123. [CrossRef] [PubMed]

156. Radhakrishnan, S.; Shimmon, R.; Conn, C.; Baker, A. Inhibitory kinetics of novel 2,3-dihydro-1H-inden-1-one chalcone-like derivatives on mushroom tyrosinase. Bioorg. Med. Chem. Lett. 2015, 25, 5495-5499. [CrossRef]

157. Brotzman, N.; Xu, Y.; Graybill, A.; Cocolas, A.; Ressler, A.; Seeram, N.P.; Ma, H.; Henry, G.E. Synthesis and tyrosinase inhibitory activities of 4-oxobutanoate derivatives of carvacrol and thymol. Bioorg. Med. Chem. Lett. 2019, 29, 56-58. [CrossRef] [PubMed]

158. Ashraf, Z.; Rafiq, M.; Seo, S.Y.; Kwon, K.S.; Babar, M.M.; Zaidi, N.U. Kinetic and in silico studies of novel hydroxy-based thymol analogues as inhibitors of mushroom tyrosinase. Eur. J. Med. Chem. 2015, 98, $203-211$. [CrossRef]

159. Ashraf, Z.; Rafiq, M.; Nadeem, H.; Hassan, M.; Afzal, S.; Waseem, M.; Afzal, K.; Latip, J. Carvacrol derivatives as mushroom tyrosinase inhibitors; synthesis, kinetics mechanism and molecular docking studies. PLoS ONE 2017, 12, e0178069. [CrossRef]

160. Iwadate, T.; Nihei, K. Rhododendrol glycosides as stereospecific tyrosinase inhibitors. Bioorg. Med. Chem. 2015, 23, 6650-6658. [CrossRef]

161. Ali, A.; Ashraf, Z.; Kumar, N.; Rafiq, M.; Jabeen, F.; Park, J.H.; Choi, K.H.; Lee, S.; Seo, S.Y.; Choi, E.H.; et al. Influence of plasma-activated compounds on melanogenesis and tyrosinase activity. Sci. Rep. 2016, 6, 21779. [CrossRef]

162. Matsumoto, T.; Nakajima, T.; Iwadate, T.; Nihei, K. Chemical synthesis and tyrosinase-inhibitory activity of isotachioside and its related glycosides. Carbohydr. Res. 2018, 465, 22-28. [CrossRef] [PubMed]

163. Kim, D.H.; Kim, S.J.; Ullah, S.; Yun, H.Y.; Chun, P.; Moon, H.R. Design, synthesis, and antimelanogenic effects of (2-substituted phenyl-1,3-dithiolan-4-yl) methanol derivatives. Drug Des. Devel. Ther. 2017, 11, 827-836. [CrossRef] [PubMed]

164. Wang, Y.; Hao, M.M.; Sun, Y.; Wang, L.F.; Wang, H.; Zhang, Y.J.; Li, H.Y.; Zhuang, P.W.; Yang, Z. Synergistic promotion on tyrosinase inhibition by antioxidants. Molecules 2018, 23, 106. [CrossRef] [PubMed]

165. Li, Q.; Yang, H.; Mo, J.; Sun, H.; Chen, Y.; Wu, Y.; Kang, C.; Sun, Y. Identification by shape-based virtual screening and evaluation of new tyrosinase inhibitors. PeerJ 2018, 6, e4206. [CrossRef] [PubMed] 
166. Ishioka, W.; Oonuki, S.; Iwadate, T.; Nihei, K. Resorcinol alkyl glucosides as potent tyrosinase inhibitors. Bioorg. Med. Chem. Lett. 2019, 29, 313-316. [CrossRef]

167. Garcia-Jimenez, A.; Teruel-Puche, J.A.; Ortiz-Ruiz, C.V.; Berna, J.; Tudela, J.; Garcia-Canovas, F. 4-n-butylresorcinol, a depigmenting agent used in cosmetics, reacts with tyrosinase. IUBMB Life 2016, 68, 663-672. [CrossRef]

168. Ortiz-Ruiz, C.V.; Berna, J.; Rodriguez-Lopez, J.N.; Tomas, V.; Garcia-Canovas, F. Tyrosinase-catalyzed hydroxylation of 4-hexylresorcinol, an antibrowning and depigmenting agent: A kinetic study. J. Agric. Food Chem. 2015, 63, 7032-7040. [CrossRef] [PubMed]

169. Ismail, T.; Shafi, S.; Srinivas, J.; Sarkar, D.; Qurishi, Y.; Khazir, J.; Alam, M.S.; Kumar, H.M.S. Synthesis and tyrosinase inhibition activity of trans-stilbene derivatives. Bioorg. Chem. 2016, 64, 97-102. [CrossRef]

170. Tanaka, Y.; Suzuki, M.; Kodachi, Y.; Nihei, K. Molecular design of potent, hydrophilic tyrosinase inhibitors based on the natural dihydrooxyresveratrol skeleton. Carbohydr. Res. 2019, 472, 42-49. [CrossRef]

171. Ashraf, Z.; Rafiq, M.; Seo, S.Y.; Babar, M.M.; Zaidi, N.U. Design, synthesis and bioevaluation of novel umbelliferone analogues as potential mushroom tyrosinase inhibitors. J. Enzyme Inhib. Med. Chem. 2015, 30, 874-883. [CrossRef]

172. Kamauchi, H.; Noji, M.; Kinoshita, K.; Takanami, T.; Koyama, K. Coumarins with an unprecedented tetracyclic skeleton and coumarin dimers from chemically engineered extracts of a marine-derived fungus. Tetrahedron 2018, 74, 2846-2856. [CrossRef]

173. Pintus, F.; Matos, M.J.; Vilar, S.; Hripcsak, G.; Varela, C.; Uriarte, E.; Santana, L.; Borges, F.; Medda, R.; Di Petrillo, A.; et al. New insights into highly potent tyrosinase inhibitors based on 3-heteroarylcoumarins: Anti-melanogenesis and antioxidant activities, and computational molecular modeling studies. Bioorg. Med. Chem. 2017, 25, 1687-1695. [CrossRef] [PubMed]

174. Molnar, M.; Kovac, T.; Strelec, I. Umbelliferone-thiazolidinedione hybrids as potent mushroom tyrosinase inhibitors. Int. J. Pharm. Res. Allied Sci. 2016, 5, 305-310.

175. Santi, M.D.; Peralta, M.A.; Puiatti, M.; Cabrera, J.L.; Ortega, M.G. Melanogenic inhibitory effects of triangularin in B16F0 melanoma cells, in vitro and molecular docking studies. Bioorg. Med. Chem. 2019, 27, 3722-3728. [CrossRef]

176. Lee, J.Y.; Cho, Y.R.; Park, J.H.; Ahn, E.K.; Jeong, W.; Shin, H.S.; Kim, M.S.; Yang, S.H.; Oh, J.S. Anti-melanogenic and anti-oxidant activities of ethanol extract of Kummerowia striata: Kummerowia striata regulate anti-melanogenic activity through down-regulation of TRP-1, TRP-2 and MITF expression. Toxicol. Rep. 2019, 6, 10-17. [CrossRef] [PubMed]

177. Maruyama, H.; Kawakami, F.; Lwin, T.T.; Imai, M.; Shamsa, F. Biochemical characterization of ferulic acid and caffeic acid which effectively inhibit melanin synthesis via different mechanisms in B16 melanoma cells. Biol. Pharm. Bull. 2018, 41, 806-810. [CrossRef] [PubMed]

178. Goenka, S.; Ceccoli, J.; Simon, S.R. Anti-melanogenic activity of ellagitannin casuarictin in B16F10 mouse melanoma cells. Nat. Prod. Res. 2019, 1-6. [CrossRef]

179. Kang, M.; Park, S.H.; Oh, S.W.; Lee, S.E.; Yoo, J.A.; Nho, Y.H.; Lee, S.; Han, B.S.; Cho, J.Y.; Lee, J. Anti-melanogenic effects of resorcinol are mediated by suppression of cAMP signaling and activation of p38 MAPK signaling. Biosci. Biotech. Biochem. 2018, 82, 1188-1196. [CrossRef]

180. Wu, Q.Y.; Wong, Z.C.F.; Wang, C.; Fung, A.H.Y.; Wong, E.O.Y.; Chan, G.K.L.; Dong, T.T.X.; Chen, Y.; Tsim, K.W.K. Isoorientin derived from Gentiana veitchiorum Hemsl. flowers inhibits melanogenesis by down-regulating MITF-induced tyrosinase expression. Phytomedicine 2019, 57, 129-136.

181. Li, H.X.; Park, J.U.; Su, X.D.; Kim, K.T.; Kang, J.S.; Kim, Y.R.; Kim, Y.H.; Yang, S.Y. Identification of anti-melanogenesis constituents from Morus alba L. leaves. Molecules 2018, 23, 2559. [CrossRef]

182. Park, S.; Jegal, J.; Chung, K.W.; Jung, H.J.; Noh, S.G.; Chung, H.Y.; Ahn, J.; Kim, J.; Yang, M.H. Isolation of tyrosinase and melanogenesis inhibitory flavonoids from Juniperus chinensis fruits. Biosci. Biotech. Biochem. 2018, 82, 2041-2048. [CrossRef] [PubMed]

183. Ha, J.H.; Park, S.N. Mechanism underlying inhibitory effect of six dicaffeoylquinic acid isomers on melanogenesis and the computational molecular modeling studies. Bioorg. Med. Chem. 2018, 26, 4201-4208. [CrossRef] [PubMed]

184. Oh, T.I.; Yun, J.M.; Park, E.J.; Kim, Y.S.; Lee, Y.M.; Lim, J.H. Plumbagin suppresses $\alpha$-MSH-induced melanogenesis in B16F10 mouse melanoma cells by inhibiting tyrosinase activity. Int. J. Mol. Sci. 2017, 18, 320. [CrossRef] [PubMed] 
185. Wang, S.T.; Chang, W.C.; Hsu, C.; Su, N.W. Antimelanogenic effect of urolithin A and urolithin B, the colonic metabolites of ellagic acid, in B16 melanoma cells. J. Agric. Food Chem. 2017, 65, 6870-6876. [CrossRef] [PubMed]

186. Abdul Hamid, M.; Abu Bakar, N.; Park, C.S.; Ramli, F.B.; Sulaiman, W.R.W. Inhibitory effect and molecular mechanism of an anti-tyrosinase in B16F1 melanoma cells by $\alpha$-mangostin, isolated from mangosteen pericarp. J. Food Nutr. Res. 2016, 4, 820-827.

187. Zhu, L.; Lu, Y.; Yu, W.G.; Zhao, X.; Lu, Y.H. Anti-photoageing and anti-melanogenesis activities of chrysin. Pharm. Biol. 2016, 54, 2692-2700. [CrossRef]

188. Nasr, B.N.; Chaabane, F.; Sassi, A.; Chekir-Ghedira, L.; Ghedira, K. Effect of apigenin-7-glucoside, genkwanin and naringenin on tyrosinase activity and melanin synthesis in B16F10 melanoma cells. Life Sci. 2016, 144, 80-85. [CrossRef]

189. Campos, P.M.; Prudente, A.S.; Horinouchi, C.D.; Cechinel-Filho, V.; Favero, G.M.; Cabrini, D.A.; Otuki, M.F. Inhibitory effect of GB-2a (I3-naringenin-II8-eriodictyol) on melanogenesis. J. Ethnopharmacol. 2015, 174, 224-229. [CrossRef]

190. Hridya, H.; Amrita, A.; Sankari, M.; George Priya Doss, C.; Gopalakrishnan, M.; Gopalakrishnan, C.; Siva, R. Inhibitory effect of brazilein on tyrosinase and melanin synthesis: Kinetics and in silico approach. Int. J. Biol. Macromol. 2015, 81, 228-234. [CrossRef]

191. Yamauchi, K.; Mitsunaga, T.; Itakura, Y.; Batubara, I. Extracellular melanogenesis inhibitory activity and the structure-activity relationships of ugonins from Helminthostachys zeylanica roots. Fitoterapia 2015, 104, 69-74. [CrossRef]

192. Imen, M.; Chaabane, F.; Nadia, M.; Soumaya, K.; Kamel, G.; Leila, C.G. Anti-melanogenesis and antigenotoxic activities of eriodictyol in murine melanoma (B16-F10) and primary human keratinocyte cells. Life Sci. 2015, 135, 173-178. [CrossRef] [PubMed]

193. Jeong, J.Y.; Liu, Q.; Kim, S.B.; Jo, Y.H.; Mo, E.J.; Yang, H.H.; Song, D.H.; Hwang, B.Y.; Lee, M.K. Characterization of melanogenesis inhibitory constituents of Morus alba leaves and optimization of extraction conditions using response surface methodology. Molecules 2015, 20, 8730-8741. [CrossRef] [PubMed]

194. Lee, S.M.; Chen, Y.S.; Lin, C.C.; Chen, K.H. Hair dyes resorcinol and lawsone reduce production of melanin in melanoma cells by tyrosinase activity inhibition and decreasing tyrosinase and microphthalmia-associated transcription factor (MITF) expression. Int. J. Mol. Sci. 2015, 16, 1495-1508. [CrossRef] [PubMed]

195. Mustapha, N.; Bzeouich, I.M.; Ghedira, K.; Hennebelle, T.; Chekir-Ghedira, L. Compounds isolated from the aerial part of Crataegus azarolus inhibit growth of B16F10 melanoma cells and exert a potent inhibition of the melanin synthesis. Biomed. Pharmacother. 2015, 69, 139-144. [CrossRef] [PubMed]

196. Cho, J.G.; Huh, J.; Jeong, R.H.; Cha, B.J.; Shrestha, S.; Lee, D.G.; Kang, H.C.; Kim, J.Y.; Baek, N.I. Inhibition effect of phenyl compounds from the Oryza sativa roots on melanin production in murine B16-F10 melanoma cells. Nat. Prod. Res. 2015, 29, 1052-1054. [CrossRef] [PubMed]

197. Kuo, Y.H.; Chen, C.C.; Wu, P.Y.; Wu, C.S.; Sung, P.J.; Lin, C.Y.; Chiang, H.M. N-(4-methoxyphenyl) caffeamide-induced melanogenesis inhibition mechanisms. BMC Complement. Altern. Med. 2017, $17,71$. [CrossRef] [PubMed]

198. Ullah, S.; Park, Y.; Ikram, M.; Lee, S.; Park, C.; Kang, D.; Yang, J.; Akter, J.; Yoon, S.; Chun, P.; et al. Design, synthesis and anti-melanogenic effect of cinnamamide derivatives. Bioorg. Med. Chem. 2018, 26, 5672-5681. [CrossRef] [PubMed]

199. Lee, S.J.; Son, Y.H.; Lee, K.B.; Lee, J.H.; Kim, H.J.; Jeong, E.M.; Park, S.C.; Kim, I.G. 4-n-butylresorcinol enhances proteolytic degradation of tyrosinase in B16F10 melanoma cells. Int. J. Cosmet.Sci. 2017, 39, $248-255$. [CrossRef]

200. Ullah, S.; Akter, J.; Kim, S.J.; Yang, J.; Park, Y.; Chun, P.; Moon, H.R. The tyrosinase-inhibitory effects of 2-phenyl-1,4-naphthoquinone analogs: Importance of the (E)- $\beta$-phenyl- $\alpha, \beta$-unsaturated carbonyl scaffold of an endomethylene type. Med. Chem. Res. 2019, 28, 95-103. [CrossRef]

201. Wang, W.; Zhang, Y.; Nakashima, S.; Wang, T.; Yoshikawa, M.; Matsuda, H. Inhibition of melanin production by anthracenone dimer glycosides isolated from Cassia auriculata seeds. J. Nat. Med. 2019, 73, 439-449. [CrossRef]

202. Son, S.; Kim, H.; Yun, H.Y.; Kim, D.H.; Ullah, S.; Kim, S.J.; Kim, Y.J.; Kim, M.S.; Yoo, J.W.; Chun, P.; et al. (E)-2-Cyano-3-(substituted phenyl)acrylamide analogs as potent inhibitors of tyrosinase: A linear $\beta$-phenyl- $\alpha, \beta$-unsaturated carbonyl scaffold. Bioorg. Med. Chem. 2015, 23, 7728-7734. [CrossRef] [PubMed] 
203. Kuo, Y.H.; Chen, C.C.; Lin, P.; You, Y.J.; Chiang, H.M. N-(4-bromophenethyl) caffeamide inhibits melanogenesis by regulating AKT/glycogen synthase kinase 3 beta/microphthalmia-associated transcription factor and tyrosinase-related protein 1/tyrosinase. Curr. Pharm. Biotechnol. 2015, 16, 1111-1119. [CrossRef] [PubMed]

204. Lu, T.M.; Ko, H.H.; Ng, L.T.; Hsieh, Y.P. Free-radical-scavenging, antityrosinase, and cellular melanogenesis inhibitory activities of synthetic isoflavones. Chem. Biodivers. 2015, 12, 963-979. [CrossRef] [PubMed]

205. Jeong, H.J.; Lee, C.S.; Choi, J.; Hong, Y.D.; Shin, S.S.; Park, J.S.; Lee, J.H.; Lee, S.; Yoon, K.D.; Ko, J. Flavokawains B and C, melanogenesis inhibitors, isolated from the root of Piper methysticum and synthesis of analogs. Bioorg. Med. Chem. Lett. 2015, 25, 799-802. [CrossRef] [PubMed]

206. Veselinovic, J.B.; Veselinovic, A.M.; Ilic-Tomic, T.; Davis, R.; O’Connor, K.; Pavic, A.; Nikodinovic-Runic, J. Potent anti-melanogenic activity and favorable toxicity profile of selected 4-phenyl hydroxycoumarins in the zebrafish model and the computational molecular modeling studies. Bioorg. Med. Chem. 2017, 25, 6286-6296. [CrossRef] [PubMed]

207. Haudecoeur, R.; Carotti, M.; Gouron, A.; Maresca, M.; Buitrago, E.; Hardre, R.; Bergantino, E.; Jamet, H.; Belle, C.; Reglier, M.; et al. 2-Hydroxypyridine-N-oxide-embedded aurones as potent human tyrosinase inhibitors. ACS Med. Chem. Lett. 2017, 8, 55-60. [CrossRef]

208. Zhou, Z.; Hou, J.; Xiong, J.; Li, M. Characterization of sulfuretin as a depigmenting agent. Fundam. Clin. Pharmacol. 2019, 33, 208-215. [CrossRef]

209. Chen, W.C.; Tseng, T.S.; Hsiao, N.W.; Lin, Y.L.; Wen, Z.H.; Tsai, C.C.; Lee, Y.C.; Lin, H.H.; Tsai, K.C. Discovery of highly potent tyrosinase inhibitor, T1, with significant anti-melanogenesis ability by zebrafish in vivo assay and computational molecular modeling. Sci. Rep. 2015, 5, 7995. [CrossRef]

210. Kwak, J.Y.; Seok, J.K.; Suh, H.J.; Choi, Y.H.; Hong, S.S.; Kim, D.S.; Boo, Y.C. Antimelanogenic effects of luteolin 7-sulfate isolated from Phyllospadix iwatensis Makino. Br. J. Dermatol. 2016, 175, 501-511. [CrossRef]

211. Kwak, J.Y.; Park, S.; Seok, J.K.; Liu, K.H.; Boo, Y.C. Ascorbyl coumarates as multifunctional cosmeceutical agents that inhibit melanogenesis and enhance collagen synthesis. Arch. Dermatol. Res. 2015, 307, 635-643. [CrossRef]

212. Moon, K.M.; Hwang, Y.H.; Yang, J.H.; Ma, J.Y.; Lee, B. Spinosin is a flavonoid in the seed of Ziziphus jujuba that prevents skin pigmentation in a human skin model. J. Funct. Foods 2019, 54, 449-456. [CrossRef]

213. Lee, S.; Lee, D.H.; Kim, J.C.; Um, B.H.; Sung, S.H.; Jeong, L.S.; Kim, Y.K.; Kim, S.N. Pectolinarigenin, an aglycone of pectolinarin, has more potent inhibitory activities on melanogenesis than pectolinarin. Biochem. Biophys. Res. Commun. 2017, 493, 765-772. [CrossRef] [PubMed]

214. Lee, B.; Moon, K.M.; Lee, B.S.; Yang, J.H.; Park, K.I.; Cho, W.K.; Ma, J.Y. Swertiajaponin inhibits skin pigmentation by dual mechanisms to suppress tyrosinase. Oncotarget 2017, 8, 95530-95541. [CrossRef] [PubMed]

215. Lee, B.; Moon, K.M.; Lim, J.S.; Park, Y.; Kim, D.H.; Son, S.; Jeong, H.O.; Kim, D.H.; Lee, E.K.; Chung, K.W.; et al. 2-(3,4-dihydroxybenzylidene)malononitrile as a novel anti-melanogenic compound. Oncotarget 2017, 8, 91481-91493. [CrossRef]

216. Ha, J.H.; Jeong, Y.J.; Xuan, S.H.; Lee, J.Y.; Park, J.; Park, S.N. Methyl-2-acetylamino-3-(4-hydroxyl-3,5dimethoxybenzoylthio) propanoate suppresses melanogenesis through ERK signaling pathway mediated MITF proteasomal degradation. J. Dermatol. Sci. 2018, 91, 142-152. [CrossRef] [PubMed]

217. Arrowitz, C.; Weber, T.; Schoelermann, A.M.; Mann, T.; Jiang, L.I.; Kolbe, L. Effective tyrosinase inhibition by thiamidol results in significant improvement of mild to moderate melasma. J. Investig. Dermatol. 2019, 139, 1691-1698. [CrossRef] [PubMed]

218. Hornyak, T.J. Next time, save mushrooms for the pizza! J. Investig. Dermatol. 2018, 138, 1470-1472. [CrossRef]

219. Mayr, F.; Sturm, S.; Ganzera, M.; Waltenberger, B.; Martens, S.; Schwaiger, S.; Schuster, D.; Stuppner, H. Mushroom tyrosinase-based enzyme inhibition assays are not suitable for bioactivity-guided fractionation of extracts. J. Nat. Prod. 2019, 82, 136-147. [CrossRef]

220. Gasowska-Bajger, B.; Wojtasek, H. Reactions of flavonoids with o-quinones interfere with the spectrophotometric assay of tyrosinase activity. J. Agric. Food Chem. 2016, 64, 5417-5427. [CrossRef]

221. Deng, H.H.; Lin, X.L.; He, S.B.; Wu, G.W.; Wu, W.H.; Yang, Y.; Lin, Z.; Peng, H.P.; Xia, X.H.; Chen, W. Colorimetric tyrosinase assay based on catechol inhibition of the oxidase-mimicking activity of chitosan-stabilized platinum nanoparticles. Mikrochim. Acta 2019, 186, 1-7. [CrossRef] 
222. Vandeput, M.; Patris, S.; Silva, H.; Parsajoo, C.; Dejaeghere, B.; Martinez, J.A.; Kauffmann, J.M. Application of a tyrosinase microreactor-detector in a flow injection configuration for the determination of affinity and dynamics of inhibitor binding. Sens. Actuator. B Chem. 2017, 248, 385-394. [CrossRef]

223. Cheng, M.; Chen, Z. Screening of tyrosinase inhibitors by capillary electrophoresis with immobilized enzyme microreactor and molecular docking. Electrophoresis 2017, 38, 486-493. [CrossRef] [PubMed]

224. Tang, L.; Zhang, W.; Zhao, H.; Chen, Z. Tyrosinase inhibitor screening in traditional Chinese medicines by electrophoretically mediated microanalysis. J. Sep. Sci. 2015, 38, 2887-2892. [CrossRef] [PubMed]

225. Zhou, J.; Tang, Q.; Wu, T.; Cheng, Z. Improved TLC bioautographic assay for qualitative and quantitative estimation of tyrosinase inhibitors in natural products. Phytochem. Anal. 2017, 28, 115-124. [CrossRef]

226. Wang, Z.; Hwang, S.H.; Huang, B.; Lim, S.S. Identification of tyrosinase specific inhibitors from Xanthium strumarium fruit extract using ultrafiltration-high performance liquid chromatography. J. Chromatogr. B Analyt. Technol. Biomed. Life Sci. 2015, 1002, 319-328. [CrossRef]

227. Chai, L.; Zhou, J.; Feng, H.; Tang, C.; Huang, Y.; Qian, Z. Functionalized carbon quantum dots with dopamine for tyrosinase activity monitoring and inhibitor screening: In vitro and intracellular investigation. ACS Appl. Mater. Interfaces 2015, 7, 23564-23574. [CrossRef]

228. Markova, E.; Kotik, M.; Krenkova, A.; Man, P.; Haudecoeur, R.; Boumendjel, A.; Hardre, R.; Mekmouche, Y.; Courvoisier-Dezord, E.; Reglier, M.; et al. Recombinant tyrosinase from Polyporus arcularius: Overproduction in Escherichia coli, characterization, and use in a study of aurones as tyrosinase effectors. J. Agric. Food Chem. 2016, 64, 2925-2931. [CrossRef]

229. Ortiz-Ruiz, C.V.; Garcia-Molina, M.; Serrano, J.T.; Tomas-Martinez, V.; Garcia-Canovas, F. Discrimination between alternative substrates and inhibitors of tyrosinase. J. Agric. Food Chem. 2015, 63, 2162-2171. [CrossRef]

230. Crescenzi, O.; Napolitano, A.; Prota, G.; Peter, M.G. Oxidative coupling of dopa with resorcinol and phloroglucinol: Isolation of adducts with an unusual tetrahydromethanobenzofuro [2,3-d] azocine skeleton. Tetrahedron 1991, 47, 6243-6250. [CrossRef]

231. Napolitano, A.; Micillo, R.; Monfrecola, G. Melanin pigmentation control by 1,3-thiazolidines: Does NO scavenging play a critical role? Exp. Dermatol. 2016, 25, 596-597. [CrossRef]

232. Shin, H.J.; Beak, H.S.; Il Kim, S.; Joo, Y.H.; Choi, J. Development and evaluation of topical formulations for a novel skin whitening agent (AP736) using Hansen solubility parameters and PEG-PCL polymers. Int. J. Pharm. 2018, 552, 251-257. [CrossRef] [PubMed]

233. Jeon, S.H.; Na, Y.G.; Lee, H.K.; Cho, C.W. Hybrid polymeric microspheres for enhancing the encapsulation of phenylethyl resorcinol. J. Microencapsul. 2019, 36, 130-139. [CrossRef] [PubMed]

234. Limsuwan, T.; Boonme, P.; Khongkow, P.; Amnuaikit, T. Ethosomes of phenylethyl resorcinol as vesicular delivery system for skin lightening applications. BioMed Res. Int. 2017, 8310979. [CrossRef] [PubMed]

235. Kim, B.S.; Na, Y.G.; Choi, J.H.; Kim, I.; Lee, E.; Kim, S.Y.; Lee, J.Y.; Cho, C.W. The improvement of skin whitening of phenylethyl resorcinol by nanostructured lipid carriers. Nanomaterials 2017, 7, 241. [CrossRef]

236. Koepke, D.; Mueller, R.H.; Pyo, S.M. Phenylethyl resorcinol smartLipids for skin brightening-Increased loading \& chemical stability. Eur. J. Pharm. Sci. 2019, 137, 104992.

237. Hespeler, D.; Kaltenbach, J.; Pyo, S.M. Glabridin smartPearls-Silica selection, production, amorphous stability and enhanced solubility. Int. J. Pharm. 2019, 561, 228-235. [CrossRef]

238. Wei, Y.; Zhang, J.; Zhou, Y.; Bei, W.; Li, Y.; Yuan, Q.; Liang, H. Characterization of glabridin/hydroxypropyl- $\beta$-cyclodextrin inclusion complex with robust solubility and enhanced bioactivity. Carbohydr. Polym. 2017, 159, 152-160. [CrossRef]

239. Chaikul, P.; Khat-udomkiri, N.; Iangthanarat, K.; Manosroi, J.; Manosroi, A. Characteristics and in vitro anti-skin aging activity of gallic acid loaded in cationic CTAB noisome. Eur. J. Pharm. Sci. 2019, 131, 39-49. [CrossRef]

240. Schlich, M.; Fornasier, M.; Nieddu, M.; Sinico, C.; Murgia, S.; Rescigno, A. 3-hydroxycoumarin loaded vesicles for recombinant human tyrosinase inhibition in topical applications. Colloids Surf. B Biointerfaces 2018, 171, 675-681. [CrossRef]

241. Fachinetti, N.; Rigon, R.B.; Eloy, J.O.; Sato, M.R.; dos Santos, K.C.; Chorilli, M. Comparative study of glyceryl behenate or polyoxyethylene 40 stearate-based lipid carriers for trans-resveratrol delivery: Development, characterization and evaluation of the in vitro tyrosinase inhibition. AAPS PharmSciTech 2018, 19, 1401-1409. [CrossRef] 
242. Rigon, R.B.; Fachinetti, N.; Chorilli, M.; Severino, P.; Santana, M.H.A. Skin delivery and in vitro biological evaluation of trans-resveratrol-loaded solid lipid nanoparticles for skin disorder therapies. Molecules 2016, 21, 116. [CrossRef] [PubMed]

243. Lee, T.H.; Kang, J.H.; Seo, J.O.; Baek, S.H.; Moh, S.H.; Chae, J.K.; Park, Y.U.; Ko, Y.T.; Kim, S.Y. Anti-melanogenic potentials of nanoparticles from calli of resveratrol-enriched rice against UVB-induced hyperpigmentation in guinea pig skin. Biomol. Ther. 2016, 24, 85-93. [CrossRef] [PubMed]

244. Shrotriya, S.; Ranpise, N.; Satpute, P.; Vidhate, B. Skin targeting of curcumin solid lipid nanoparticles-engrossed topical gel for the treatment of pigmentation and irritant contact dermatitis. Artif. Cells Nanomed. Biotechnol. 2018, 46, 1471-1482. [CrossRef] [PubMed]

245. Al-Amin, M.; Cao, J.; Naeem, M.; Banna, H.; Kim, M.S.; Jung, Y.; Chung, H.Y.; Moon, H.R.; Yoo, J.W. Increased therapeutic efficacy of a newly synthesized tyrosinase inhibitor by solid lipid nanoparticles in the topical treatment of hyperpigmentation. Drug Des. Devel. Ther. 2016, 10, 3947-3957. [CrossRef]

246. Parisi, O.I.; Malivindi, R.; Amone, F.; Ruffo, M.; Malanchin, R.; Carlomagno, F.; Piangiolino, C.; Nobile, V.; Pezzi, V.; Scrivano, L.; et al. Safety and efficacy of dextran-rosmarinic acid conjugates as innovative polymeric antioxidants in skin whitening: What is the evidence? Cosmetics 2017, 4, 28. [CrossRef]

(C) 2019 by the authors. Licensee MDPI, Basel, Switzerland. This article is an open access article distributed under the terms and conditions of the Creative Commons Attribution (CC BY) license (http://creativecommons.org/licenses/by/4.0/). 